\title{
Zinc oxide nanoparticles induce apoptosis and autophagy in human ovarian cancer cells
}

\author{
This article was published in the following Dove Press journal: \\ International Journal of Nanomedicine \\ 5 September 2017 \\ Number of times this article has been viewed
}

\author{
Ding-Ping Bai ${ }^{1, *}$ \\ Xi-Feng Zhang',* \\ Guo-Liang Zhang 3 ,4 \\ Yi-Fan Huang' \\ Sangiliyandi Gurunathan ${ }^{5}$ \\ 'Fujian Key Laboratory of Traditional \\ Chinese Veterinary Medicine and \\ Animal Health, Fujian Agriculture \\ and Forestry University, Fuzhou, \\ China; ${ }^{2}$ College of Biological and \\ Pharmaceutical Engineering, Wuhan \\ Polytechnic University, Wuhan, China; \\ ${ }^{3}$ Dong-E-E-Jiao Co., Ltd., Shandong, \\ China; ${ }^{4}$ National Engineering \\ Research Center for Gelatin-based \\ Traditional Chinese Medicine, \\ Shandong, China; ${ }^{5}$ Department \\ of Stem Cell and Regenerative \\ Biotechnology, Konkuk University, \\ Seoul, Republic of Korea \\ *These authors contributed equally \\ to this work
}

Background: Zinc oxide nanoparticles (ZnO NPs) are frequently used in industrial products such as paint, surface coating, and cosmetics, and recently, they have been explored in biologic and biomedical applications. Therefore, this study was undertaken to investigate the effect of $\mathrm{ZnO}$ NPs on cytotoxicity, apoptosis, and autophagy in human ovarian cancer cells (SKOV3). Methods: ZnO NPs with a crystalline size of $20 \mathrm{~nm}$ were characterized with various analytical techniques, including ultraviolet-visible spectroscopy, X-ray diffraction, transmission electron microscopy, Fourier transform infrared spectroscopy, and atomic force microscopy. The cytotoxicity, apoptosis, and autophagy were examined using a series of cellular assays.

Results: Exposure of cells to $\mathrm{ZnO}$ NPs resulted in a dose-dependent loss of cell viability, and the characteristic apoptotic features such as rounding and loss of adherence, enhanced reactive oxygen species generation, and loss of mitochondrial membrane potential were observed in the ZnO NP-treated cells. Furthermore, the cells treated with ZnO NPs showed significant double-strand DNA breaks, which are gained evidences from significant number of $\gamma-\mathrm{H}_{2} \mathrm{AX}$ and Rad51 expressed cells. ZnO NP-treated cells showed upregulation of p53 and LC3, indicating that $\mathrm{ZnO}$ NPs are able to upregulate apoptosis and autophagy. Finally, the Western blot analysis revealed upregulation of Bax, caspase-9, $\operatorname{Rad} 51, \gamma-\mathrm{H}_{2} \mathrm{AX}, \mathrm{p} 53$, and LC3 and downregulation of Bcl-2.

Conclusion: The study findings demonstrated that the $\mathrm{ZnO}$ NPs are able to induce significant cytotoxicity, apoptosis, and autophagy in human ovarian cells through reactive oxygen species generation and oxidative stress. Therefore, this study suggests that ZnO NPs are suitable and inherent anticancer agents due to their several favorable characteristic features including favorable band gap, electrostatic charge, surface chemistry, and potentiation of redox cycling cascades.

Keywords: zinc oxide nanoparticles, human ovarian cancer cells SKOV3, mitochondrial membrane potential, apoptosis, DNA fragmentation, autophagy

\section{Introduction}

Nanotechnology represents a new and enabling platform to produce novel nanomaterials for a broad range of biologic and biomedical applications. Nanoscience and nanotechnology attracted much interest during the past decade due to the unique and exciting physical and chemical properties of the nanomaterials, and they have been used for a broad range of applications. ${ }^{1}$ One of the major advantages of nanotechnology is its ability to produce nanomaterials measuring $<100 \mathrm{~nm}$ in a controlled manner. Metal oxide in the nanorange acquires distinct properties that depend on the size, chemical composition, and surface chemistry. Metal oxide nanoparticles (NPs) such as ZnO NPs have been extensively used in cosmetic lotions, as these compounds are known to possess effective UV absorbing properties, thereby acting as successful UV blockers. ${ }^{2}$
Correspondence: Sangiliyandi Gurunathan Department of Stem Cell and Regenerative Biotechnology, Konkuk University, Seoul I43-70I, Republic of Korea

Tel +82 2450 058I

Email gsangiliyandi@yahoo.com
International Journal of Nanomedicine 2017:12 6521-6535

Dovepress f 10

http://dx.doi.org/10.2147uIN.S1 40071 (c) (1) (5) 2017 Bai et al. This work is published and licensed by Dove Medical Press Limited. The full terms of this license are available at https://www.dovepress.com/terms.php cc) ${ }_{\mathrm{BY}} \mathrm{NC}$ and incorporate the Creative Commons Attribution - Non Commercial (unported, v3.0) License (http://creativecommons.org/licenses/by-n/3.0/). By accessing the work you hereby accept the Terms. Non-commercial uses of the work are permitted without any further permission from Dove Medical Press Limited, provided the work is properly attributed. For permission for commercial use of this work, please see paragraphs 4.2 and 5 of our Terms (https://www.dovepress.com/terms.php). 
Commonly, $\mathrm{ZnO}$ NPs have been used for industrial purposes such as usage as semiconductors in microelectronic devices and for accelerating degradation of water pollutants by photocatalytic activity. Moreover, recently, ZnO NPs have been found to have the potential for use in biomedical and cancer applications due to the attractive chemical properties of these nanomaterials. ${ }^{3}$ Previous studies reported that $\mathrm{ZnO}$ NPs exhibit a high degree of cancer cell selectivity with the ability to surpass the therapeutic indices, compared to chemotherapeutic agents. ${ }^{4,5}$

Cancer is a condition of uncontrolled cell differentiation, which has been treated by several modalities, including chemotherapy, radiation, and surgery, during the past several decades. ${ }^{6}$ Although all these therapies seem to be effective for destruction of cells, they have nonselective and severe side effects. To overcome these side effects, recently, nanomedicine-mediated modalities have been shown much interest in cancer therapy due to their active/ passive targeting, high solubility/bioavailability, biocompatibility, and multifunctionality. ${ }^{7}$ Among several metal NPs, $\mathrm{ZnO}$ NPs show enhanced cytotoxicity by generation of reactive oxygen species (ROS), leading to oxidative stress and eventually cell death, when the antioxidative capacity of the cell is exceeded. ${ }^{3}$ ROS are oxygen metabolites that are highly active in terms of oxidative modifications of cellular macromolecules including proteins, lipids, and polynucleotides. ${ }^{8}$ The cellular redox homeostasis is maintained by the balance between ROS production and the antioxidant system in the cell; when ROS is produced excessively or endogenous antioxidant capacity is diminished, indiscriminate oxidation elicits harmful effects, resulting in "oxidative stress". Several studies proved that excessive oxidative stress is harmful to the cell and causes sever cytotoxicity. ${ }^{8}$ Mitochondria are the source of ROS. Once the level of ROS is exceeded, the mitochondrial integrity and membrane structures are damaged; ultimately, the redox balance system is compromised, which eventually leads to mitochondrial dysfunction and also causes severe damage to cellular macromolecules, especially DNA. ${ }^{9}$ The extent of DNA damage determines the cell fate by cell cycle arrest, DNA repair or activation of apoptotic pathways. ${ }^{10,11}$ Furthermore, DNA damage results in chromosomal breakage and micronuclei formation. The loss of mitochondrial membrane potential (MPT) leads to exposure of cytochrome $c$ into the intermembrane space, and the leakage of cytochrome $c$ is responsible for activation of caspases. ${ }^{12}$ Therefore, ROS is a major and critical player for both apoptosis and autophagy, which lead to cell death. ${ }^{13}$ Excessive cellular damage may lead to cell death by overstimulating autophagy and cellular self-consumption. ${ }^{14}$
Previous studies have reported the cytotoxicity of $\mathrm{ZnO}$ NPs in various types of cancer cells by increased oxidative stress, increased intracellular $\left[\mathrm{Ca}^{2+}\right]$ level, and decreased MPT. ZnO NPs stimulate interleukin (IL)-8 production in the BEAS-2B bronchial epithelial cells and A549 alveolar adenocarcinoma cells, ${ }^{15}$ and they reduce MPT, loss of membrane integrity, and activation of p53 pathway in RAW264.7 cells. ${ }^{16,17}$ Furthermore, ZnO NPs are able to induce various proinflammatory markers including interferon-c, tumor necrosis factor- $\alpha$, and IL-12 in peripheral blood mononuclear cells. The expression of IL-1 $\beta$ and chemokine CXCL9 is also induced in murine bone marrow-derived dendritic cells and RAW264.7 murine macrophages. ${ }^{18} \mathrm{ZnO}$ NPs not only induce cytotoxicity, but also cause a variety of genotoxicity in various type of cells, including DNA damage in the A431 human epidermal cells, ${ }^{19}$ and also induce micronuclei production, H2AX phosphorylation, and DNA damage in human SHSY5Y neuronal cells. ${ }^{20}$ Several studies demonstrated that involvement of various signaling pathways including c-Jun $\mathrm{N}$-terminal kinase, extracellular signal-related kinase, and p38 mitogen-activated protein kinase in $\mathrm{ZnO}$ NPs induced apoptosis, which is specifically activated by oxidative stress, ${ }^{21}$ and also that metal NPs could induce mitochondrial apoptotic pathway by activation of proapoptotic proteins, downregulation of Bcl-2, activation of PARP and caspase cascades, and DNA fragmentation in human neural cells and fibroblasts, PC12 cells, and human breast cancer cells. ${ }^{22-24}$

Although currently several anticancer chemotherapies are available, they fail to produce a complete anticancer response due to the development of drug resistance or their failure to effectively differentiate between cancerous and normal cells, and also, they require large quantity of drug administration. ${ }^{3}$ Among several NPs used in anticancer therapy, ZnO NPs exhibit a high degree of cancer cell selectivity. They are able to preferentially target rapidly dividing cancerous cells, which could serve as a foundation for developing novel cancer therapeutics. Therefore, this study was designed to investigate the cytotoxic potential of ZnO NPs in human ovarian cancer cells.

\section{Materials and methods Characterization of $\mathrm{ZnO}$ NPs}

$\mathrm{ZnO}$ NPs (about $20 \mathrm{~nm}$ ) were obtained from Beijing DK nanotechnology Co. Ltd. The size, shape, and dispersion of $\mathrm{ZnO}$ NPs were evaluated by transmission electron microscopy (TEM, H-7500; Hitachi Ltd., Tokyo, Japan). X-ray diffraction (XRD) data were collected on aD8 Advance X-ray Powder Diffractometer (Bruker Optik GmbH, Ettlingen, Germany). Ultraviolet-visible (UV-vis) spectra were 
recorded using an OPTIZEN spectrophotometer (Hitachi Ltd.). The surface chemical bonding and composition of NPs were characterized using a Fourier transform infrared spectroscopy (FTIR) instrument (Spectroscopy GX; PerkinElmer Inc., Branford, CT, USA). Atomic force microscopy (AFM) was used for evaluating the surface morphology and properties of the $\mathrm{ZnO}$ NPs.

\section{Cell culture and exposure of cells to $\mathrm{ZnO} \mathrm{NPs}$}

Ovarian cancer cell line (SKOV3 cells) was obtained from Sigma-Aldrich and cultured in DMEM (Hyclone, Logan, UT, USA) supplemented with fetal bovine serum (10\%) and antibiotics (penicillin $100 \mathrm{U} / \mathrm{mL}$ and streptomycin $100 \mu \mathrm{g} / \mathrm{mL}$ ) at $37^{\circ} \mathrm{C}$ in a $5 \% \mathrm{CO}_{2}$ atmosphere. The cells were seeded onto plates at a density of $1 \times 10^{4}$ cells per well and incubated for 24 $\mathrm{h}$ prior to the experiments. The cells were washed with PBS ( $\mathrm{pH}$ 7.4) and incubated in fresh medium containing different concentrations of $\mathrm{ZnO}$ NPs dissolved in water.

\section{Cell morphology}

Ovarian cancer cells were plated in six-well plates $\left(2 \times 10^{5}\right.$ cells per well) and incubated with $\mathrm{ZnO}$ NPs for $24 \mathrm{~h}$. Cells cultured in medium without the addition of $\mathrm{ZnO}$ NPs were used as the control. The cell morphology was analyzed using an optical microscope at $24 \mathrm{~h}$ posttreatment. The morphology of the cells was examined with an OLYMPUS IX71 microscope (Olympus Corporation, Tokyo, Japan) using the appropriate filter sets.

\section{Cytotoxicity assays of ZnO NPs}

The MTT assay was used to investigate mitochondrial function. In brief, $1 \times 10^{4}$ cells were seeded in each 96 -well plate and exposed to different concentrations of $\mathrm{ZnO}$ NPs for 12 and $24 \mathrm{~h}$. After the exposure was completed, the culture medium was removed from each well and replaced with $100 \mu \mathrm{L}$ of new medium containing MTT and incubated for $3 \mathrm{~h}$ at $37^{\circ} \mathrm{C}$. The absorbance was measured at $450 \mathrm{~nm}$ using a microplate reader (PerkinElmer Inc., Waltham, MA, USA). Lactate dehydrogenase (LDH) leakage assay was carried out using the LDH cytotoxicity assay kit (Abcam, Cambridge, UK). LDH activity was determined in the spent medium by measuring the absorbance at $490 \mathrm{~nm}$ using a Multiskan FC multiplate reader.

\section{Measurement of ROS levels}

Intracellular ROS levels were measured using the detection kit no S0033 purchased from Beyotime (Jiangsu, China). Briefly, cells were seeded in six-well plates for $24 \mathrm{~h}$ and then incubated with fresh medium containing $10 \mu \mathrm{M}$ dichlorodihydrofluorescein diacetate (DCFH-DA) at $37^{\circ} \mathrm{C}$ in the dark for $20 \mathrm{~min}$. Subsequently, the cells were treated with different concentrations of ZnO NPs for $12 \mathrm{~h}$. At the end of incubation, the cells were washed with PBS and the $2^{\prime}, 7^{\prime}$-dichlorofluorescein (DCF) fluorescence intensity was measured under a fluorescence microscope using image analysis software. Images were captured with an electronic camera (Olympus Corporation; 100 magnification).

\section{JC-I assays}

JC-1 assay was performed according to the manufacturer's instructions (JC-1 Mitochondrial Membrane Potential Assay Kit; Abnova, Taipei City, Taiwan). Cells were cultured with different concentrations of $\mathrm{ZnO}$ NPs for $12 \mathrm{~h}$ under the conditions described above. They were then transferred onto a coverslip housed in a four-well plate and incubated in DMEM containing $10 \mu \mathrm{M} \mathrm{JC}-1$ at $37^{\circ} \mathrm{C}$ for $15 \mathrm{~min}$ before washing with PBS and rapidly mounted for observation. In all procedures, cells were mounted with Vectashield fluorescence medium and visualized under a fluorescent microscope.

\section{Terminal deoxynucleotidyl transferase- mediated dUTP nick end labeling analysis}

For detection of apoptotic cells in the $\mathrm{ZnO}$ NP-treated group, the terminal deoxynucleotidyl transferase-mediated dUTP nick end labeling (TUNEL) method was employed, using an in situ detection kit (Promega Corporation, Fitchburg, WI, USA) according to the manufacturer's instructions. Cells were treated with different concentrations of ZnO NPs for $12 \mathrm{~h}$, and then cell apoptosis was quantified using TUNEL analysis. Samples were evaluated under a fluorescence microscope Nikon Eclipse E400, Nikon 40× Plan 40/0.65. Differences between the number of TUNEL-positive cells in the control and experimental samples were statistically analyzed.

\section{Immunohistochemistry}

Cells were incubated with ZnO NPs for $12 \mathrm{~h}$, fixed in 4\% paraformaldehyde, and blocked with $1 \%$ bovine serum albumin for $30 \mathrm{~min}$. Then, they were incubated with primary antibodies against $\gamma$-H2AX (ab26350; Abcam) or Rad51 (ab88572; Abcam), p53 (ab1431; Abcam) or LC3 (ab51520; Abcam) at $4^{\circ} \mathrm{C}$ overnight. After washing with PBS, the cells were labeled with $\mathrm{Cy} 3$-labeled goat anti-rabbit IgG at a dilution of 1:50 (A0516; Beyotime) at $4^{\circ} \mathrm{C}$ for $1.5 \mathrm{~h}$. Finally, the samples were counterstained with $4^{\prime}, 6$-diamidino2-phenylindole and visualized under a confocal microscope (Carl Zeiss LSM780; Instrument Development Center, NCKU, Tainan City, Taiwan). 


\section{Western blot analysis}

For Western blot analysis, the cells were treated with $\mathrm{ZnO}$ NPs $(30 \mu \mathrm{g} / \mathrm{mL})$ for $12 \mathrm{~h}$. The harvested cell pellets were incubated in RIPA lysis buffer in the presence of a protease inhibitor. Protein concentrations were measured using BCA Protein Assay Reagent (Pierce, Rockford, IL, US). The cell lysates were then analyzed for protein content using sodium dodecyl sulfate-polyacrylamide gel electrophoresis. The membrane was probed with antibodies to determine the level of protein expression. The following primary antibodies were used: anti- $\gamma$-H2AX (ab26350; Abcam), anti-Rad51 (ab88572; Abcam), anti-Caspase-9 (ab202068; Abcam), anti-p53 (ab1431; Abcam), anti-LC3 (ab51520; Abcam), anti-BAX (\#2772; Cell Signaling Technology, Boston, MA, USA), anti-Bcl2 (YT0470; ImmunoWay, SuZhou, China), and anti- $\beta$-action (ab8227; Abcam).

\section{Statistical methods}

Independent experiments were repeated at least three times, so that data were represented as mean $\pm \mathrm{SD}$ for all duplicates within an individual experiment. Data were analyzed by Student $t$-test or one-way analysis of variance followed by the Tukey test for multiple comparisons to determine the differences between groups (denoted by an asterisk or different letters) using GraphPad Prism analysis software.

\section{Results and discussion Characterization of $\mathrm{ZnO}$ NPs}

UV-vis spectroscopy is an important analytical tool for characterization of NPs, which could provide the proof of synthesis of $\mathrm{ZnO}$ due to characteristic absorption spectra at 300-380 nm. The size of the NPs plays an important role in changing the entire properties of the materials. UV-vis absorption spectroscopy is a widely being used technique to examine the optical properties of nanosized particles. The absorption spectrum of $\mathrm{ZnO}$ nanopowder is shown in Figure 1A. It exhibits a strong absorption band at about $367 \mathrm{~nm}$, which is consistent with previous publications. ${ }^{25-27}$ Nagarajan and Arumugam Kuppusamy ${ }^{28}$ synthesized $\mathrm{ZnO}$ NP using seaweeds of Gulf of Mannar with various concentrations of sea weed filtrate, which showed typical absorption spectra at $372 \mathrm{~nm}$. It is also evident that significant sharp absorption of $\mathrm{ZnO}$ indicates the monodispersed nature of the NP distribution. ${ }^{26,29}$ The absorption spectroscopy data revealed that both the chemically and biologically prepared $\mathrm{ZnO}$ NPs showed similar spectral images.

Figure $1 \mathrm{~B}$ represents the $\mathrm{XRD}$ pattern of $\mathrm{ZnO}$ nanopowder. A definite line broadening of the XRD peaks indicates that the prepared material consisted of particles in nanoscale range. From this XRD pattern analysis, we determined the peak intensity, position and width, and full width at half maximum data. The diffraction peaks located at $32.84^{\circ}$, $34.52^{\circ}, 36.33^{\circ}, 46.63^{\circ}, 57.71^{\circ}, 63.96^{\circ}, 68.13^{\circ}$, and $69.18^{\circ}$ have been keenly indexed as hexagonal wurtzite phase of $\mathrm{ZnO},{ }^{29,30}$ and it also confirms further that the synthesized nanopowder was free of impurities as it did not contain any characteristic XRD peaks other than $\mathrm{ZnO}$ peaks. According to the diffraction pattern, the synthesized $\mathrm{ZnO}$ NP diameter was $20 \mathrm{~nm}$ using Debye-Scherrer formula.

TEM was used to determine the size and shape of NPs. Generally, ZnO NPs appeared as agglomerated form without any definite size and shape. The fine powder of $\mathrm{ZnO}$ nanocrystals was dispersed in ethanol on a carbon-coated copper grid and the high-resolution TEM images were obtained with ultrahigh resolution at an accelerating voltage of $200 \mathrm{kV}$. The average crystal size was estimated considering the number of crystals and it was found to be $20 \mathrm{~nm}$ (Figure 1C). TEM result of zinc oxide NPs showed $20 \mathrm{~nm}$. Consistent with our results, Nagarajan and Arumugam Kuppusamy ${ }^{28}$ produced ZnO NPs with an average size of $20-36 \mathrm{~nm}$ at a higher temperature using sea weed filtrate.

Figure 1D shows the FTIR spectra of ZnO NPs. Infrared studies were performed to confirm the purity and nature of the metal NPs. The FTIR measurements of the ZnO NPs showed peaks at $3,445 \mathrm{~cm}^{-1}$ (phosphorous compounds, secondary sulfonamide), $2,922 \mathrm{~cm}^{-1}$ (monosubstituted alkynes, $\beta$-lactones, amine salts), 1,628 $\mathrm{cm}^{-1}$ (medium charge vinyl, cis-trisubstituted), $1,387 \mathrm{~cm}^{-1}$ (amide II), and $1,111 \mathrm{~cm}^{-1}$ (monosubstituted alkyne). ${ }^{29}$ The peaks observed at 3,445 and $1,111 \mathrm{~cm}^{-1}$ indicate that $\mathrm{O}-\mathrm{H}$ stretching and deformation, respectively assigned to the water adsorption on the metal surface. The peaks at 1,628 and $439 \mathrm{~cm}^{-1}$ correspond to stretching vibration of $\mathrm{C}-\mathrm{N}$ and $\mathrm{OH}$, respectively. The metal-oxygen frequencies observed for the respective metal oxides are in accordance with literature values. ${ }^{31}$ The data obtained from our study show significant agreement with $\mathrm{ZnO}$ NPs prepared by microemulsion route. ${ }^{32}$

AFM is an important technique for the morphologic characterization of ZnO NPs and can be used to image and evaluate their surface morphologies and properties. ${ }^{29}$ Figure 1E (left panel) is a typical AFM image of ZnO NPs dispersion in water after their deposition on a freshly cleaned glass surface. The average width of the as-prepared $\mathrm{ZnO}$ NPs was measured from the size of the AFM image; the size of A-B was $26.96 \mathrm{~nm}$, the size of C-D was $33.33 \mathrm{~nm}$ (Figure 1E, right panel), and the size of E-F was $22.15 \mathrm{~nm}$. 
A

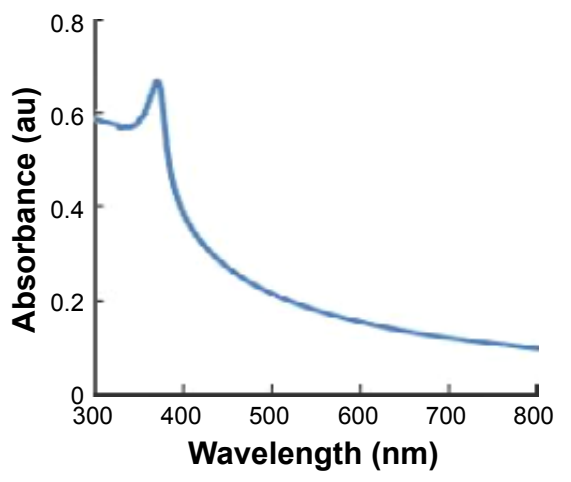

B

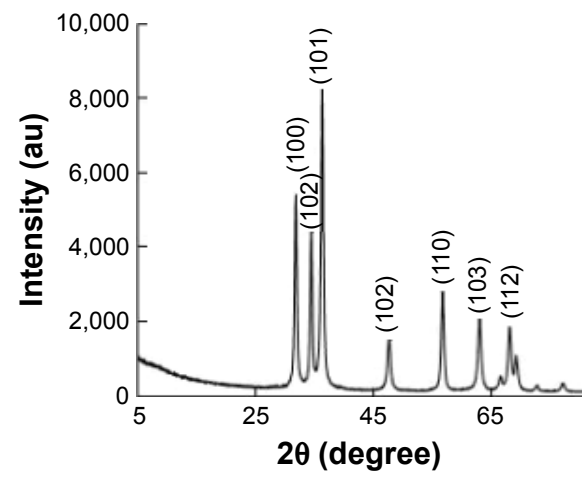

C

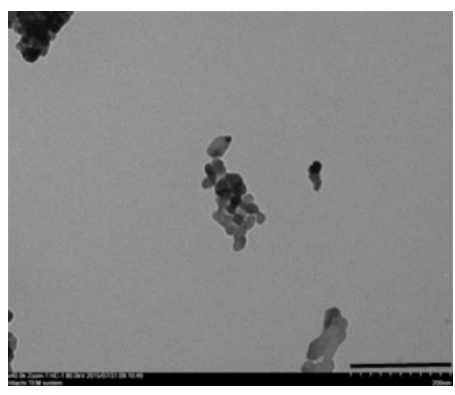

D

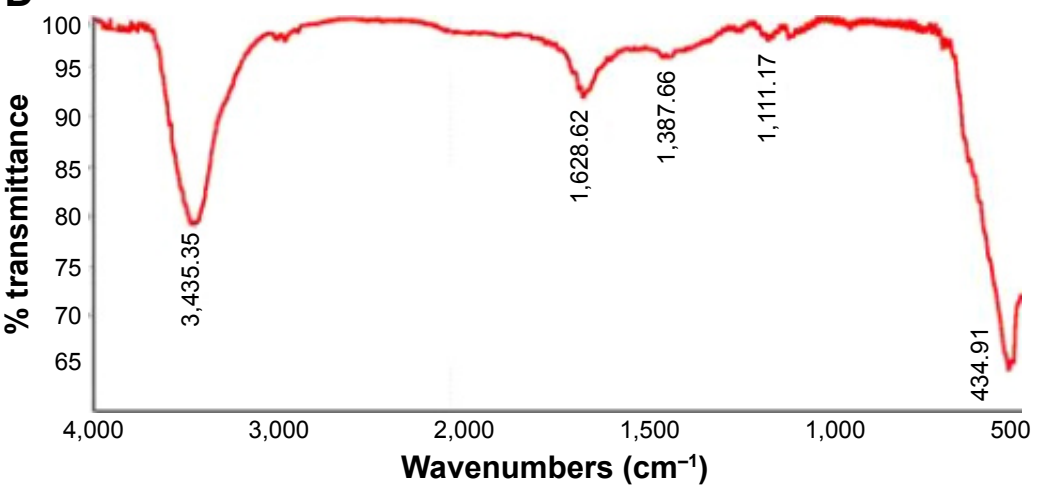

E

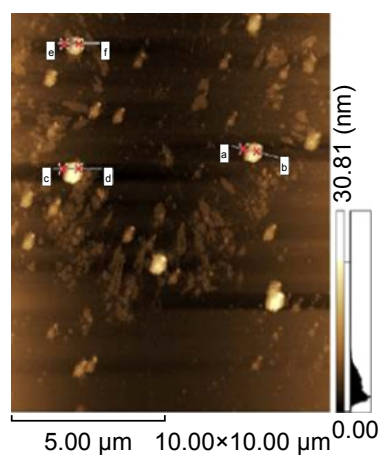

a-b 26.96

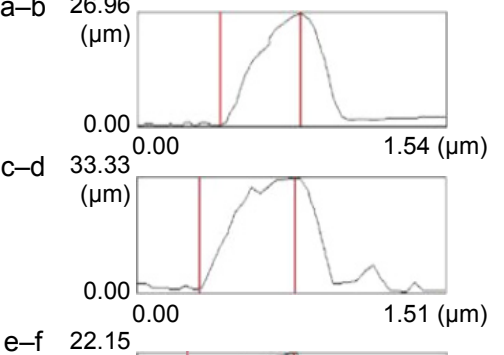

e-f 22.15

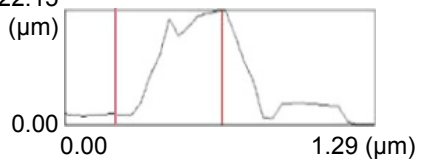

Figure I Characterization of ZnO NPs by UV-visible spectroscopy, XRD, TEM, FTIR, and AFM.

Notes: (A) UV-visible spectroscopy, (B) XRD spectrum, (C) TEM, (D) FITR, and (E) AFM. At least three independent experiments were performed for each sample and reproducible results were obtained. The results of a representative experiment are presented. Scale bar $200 \mathrm{~nm}$.

Abbreviations: AFM, atomic force microscopy; FTIR, Fourier transform infrared; TEM, transmission electron microscopy; UV, ultraviolet; XRD, X-ray diffraction; $\mathrm{ZnO}$ NPs, zinc oxide nanoparticles.

AFM showed the topographic image of well-dispersed $\mathrm{ZnO}$ NPs, which further confirmed the size of the NPs of around $30.81 \mathrm{~nm}$; this is consistent with that of biologically synthesized $\mathrm{ZnO}$ NPs. ${ }^{28,33}$ The data derived from AFM corroborate with the data obtained from TEM and XRD analysis. Eita et $\mathrm{a}^{34}$ observed that $\mathrm{ZnO}$ NPs stabilized with cationic surfactant showed high surface roughness of $22.9 \mathrm{~nm}$, in comparison with the average thickness of the film, and that the size of the $\mathrm{ZnO} N P s, 30.81 \mathrm{~nm}$, indicates that the multilayer is highly porous with random adsorption of $\mathrm{ZnO}$ NPs. The tip-corrected NPs are shown with an average size of $30.81 \mathrm{~nm}$, which is consistent with biologically prepared $\mathrm{ZnOP}$ using sea weeds. ${ }^{28}$

\section{Effect of ZnO NPs on cell viability and cell morphology}

Figure 2 shows the dose-dependent response for changes in cell viability of human ovarian cancer cells after exposure 


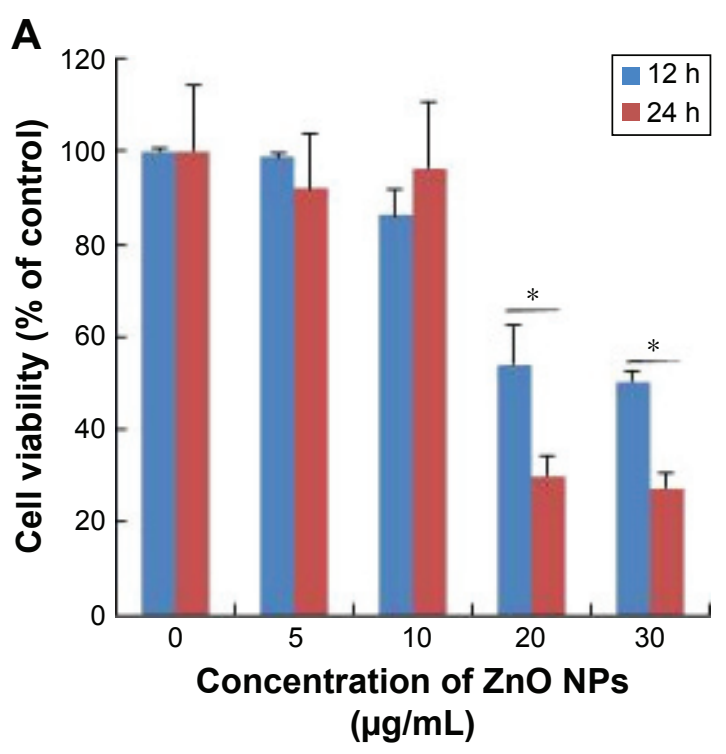

B $0 \mu \mathrm{g} / \mathrm{mL}$ $5 \mu \mathrm{g} / \mathrm{mL}$ $10 \mu \mathrm{g} / \mathrm{mL}$
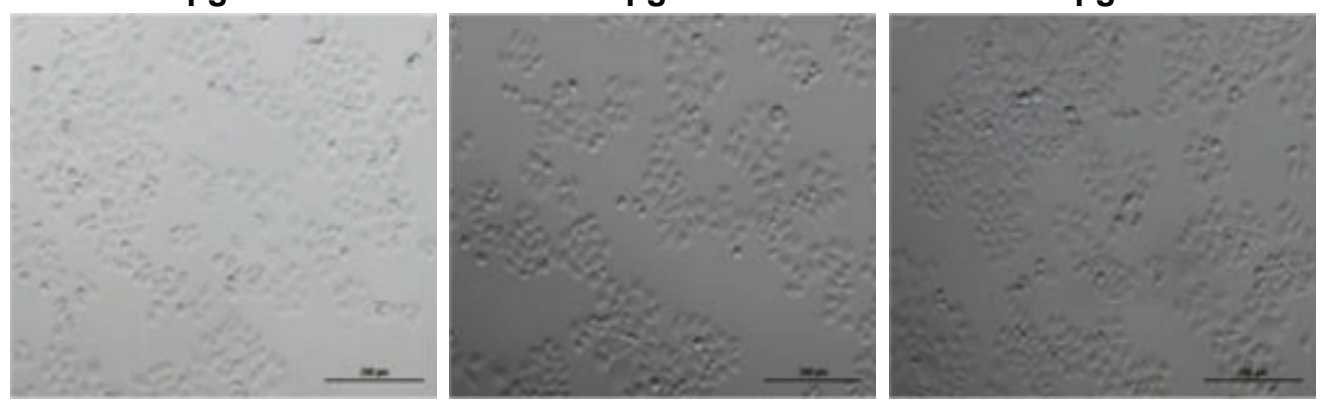

$20 \mu \mathrm{g} / \mathrm{mL}$

$30 \mu \mathrm{g} / \mathrm{mL}$
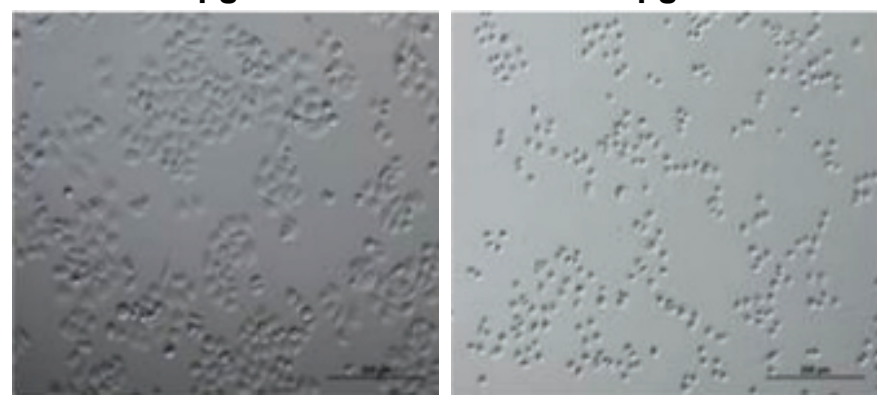

Figure 2 Effects of ZnO NPs on cell viability and cell morphology.

Notes: SKOV3 cells were incubated with different concentrations of ZnO NPs for 12 and 24 h, and then the viability of SKOV3 cells was determined using WST-8 assay. (A) The results are expressed as the mean \pm standard deviation of three independent experiments. A significant difference was observed between control and treated cells. The viability of treated cells was compared to that of the untreated cells using Student's $t$-test $(* P<0.05)$. (B) Phase contrast microscopy data showing the morphologic appearance of SKOV3 cells after treatment with ZnO NPs for $12 \mathrm{~h}$. Scale bars $=200 \mu \mathrm{m}$.

Abbreviation: $\mathrm{ZnO}$ NPs, zinc oxide nanoparticles.

to $\mathrm{ZnO}$ NPs. The results depicted that there was a significant reduction in cell viability following treatment with 20 and $30 \mu \mathrm{g} / \mathrm{mL}(P<0.05)$. Although significant differences in cell viability were observed between 10 and $30 \mu \mathrm{g} / \mathrm{mL}$, a remarkable difference was observed only between 20 and $30 \mu \mathrm{g} / \mathrm{mL}$. The cell viability of human ovarian cancer cells decreased significantly in a time- and dose-dependent manner during the $24 \mathrm{~h}$ exposure to 20 and $30 \mu \mathrm{g} / \mathrm{mL} \mathrm{ZnO} \mathrm{NPs}(P<0.05)$, as shown in Figure 2A. No significant difference in cell viability was observed on exposure to a lower concentration, 5 and $10 \mu \mathrm{g} / \mathrm{mL}$, between 12 and $24 \mathrm{~h}$. Altogether, significant effect was observed at higher concentration (20 and $30 \mu \mathrm{g} / \mathrm{mL}$ ) at $24 \mathrm{~h}$; nevertheless, at an increasing concentration from 20 to $30 \mu \mathrm{g} / \mathrm{mL}$, a significant difference in cell viability was observed. Therefore, 20 and $30 \mu \mathrm{g} / \mathrm{mL}$ seem to be workable concentrations that are sufficient to know the effect of $\mathrm{ZnO}$ 
NPs in ovarian cancer cells (Figure 2A). Lee et al ${ }^{15}$ reported the toxic effect of $\mathrm{ZnO}$ NPs on human epidermal keratinocyte $\mathrm{HaCaT}$ cells after exposure to concentrations of $0,10,20$, 40 , and $80 \mu \mathrm{g} / \mathrm{mL}$ for $24 \mathrm{~h}$. The results revealed that $\mathrm{ZnO}$ NPs reduced the mitochondrial function and induced leakage of LDH. In addition, ZnO NPs induced oxidative stress, due to which ROS and LPO were produced. Consistent with our results, concentration-dependent effect was observed in human pulmonary adenocarcinoma cell line LTEP-a- $2{ }^{36}$ Chuang et a ${ }^{37}$ demonstrated the effect of two different sizes of $\mathrm{ZnO} \mathrm{NPs}$, such as 20 and $90 \mathrm{~nm}$, in human coronary artery endothelial cells. Exposure of human coronary artery endothelial cells to $\mathrm{ZnO}$ NPs resulted in decreased cell viability and increased levels of 8-oxo-2'-deoxyguanosine, IL-6, and nitric oxide. ZnO NPs were internalized by Leydig cells and Sertoli cells, and this resulted in cytotoxicity in a time- and dose-dependent manner through the induction of apoptosis. ${ }^{29}$

Next we examined the effect of ZnO NPs on cell morphology. The observation of morphologic nature of cells could indicate the apoptotic status of cells. To determine the cell morphology, the cells were treated with various concentrations of ZnO NPs $(5,10,20$, and $30 \mu \mathrm{g} / \mathrm{mL})$. The results showed that control cells were distinct in shape with elongated spindle morphology and a regular cell margin. However, the cells treated with $5-30 \mu \mathrm{g} / \mathrm{mL}$ of $\mathrm{ZnO}$ NPs showed significant morphologic changes of cell damage (Figure 2B). However, at a higher concentration, such as 20 and $30 \mu \mathrm{g} / \mathrm{mL}$, the majority of cells were round in shape with a shrunken morphology (Figure 2B). At $30 \mu \mathrm{g} / \mathrm{mL}$, the numbers of cells with round shape morphology were higher than the cells exposed to 5,10 , or $20 \mu \mathrm{g} / \mathrm{mL}$. Cells exposed to $20 \mu \mathrm{g} / \mathrm{mL} \mathrm{ZnO}$ NPs demonstrated no morphologic changes in L929 cells, whereas higher concentration of NPs induced the cells to become rounded up and lose their spindle shape morphologic features. ${ }^{38} \mathrm{ZnO}$ NP-treated astrocytes exhibited numerous lamellapodia and filopodia that were found projecting from the cell membranes over the substratum, which were probably formed by the aggregation of ZnO NPs in random clusters at the cell surface. ${ }^{39}$ The data from cell viability and cell morphologic analysis provided evidence for the increasing number of shrinking cells in a dose-dependent manner (Figure 2B). The increasing morphologic changes in the presence of ZnO NPs coincided well with the decline in cell survival rate; thus, they were associated with proliferation inhibition and/or cell death. ${ }^{40}$ Similarly, Pandurangan et al demonstrated that $\mathrm{ZnO}$ NPs significantly induced morphologic changes such as loss of cell-cell and cell-substrate adherence and rounding of cells in human cervical carcinoma cells. However, they concluded that cell alteration depends on the size, concentration, and type of cells. ${ }^{41}$

\section{Effect of $\mathrm{ZnO}$ NPs on intracellular ROS level}

The generation of intracellular ROS seems to be an important player for $\mathrm{ZnO} \mathrm{NP}$-induced cell death. Increasing the level of ROS leads to decrease in the level of antioxidative system in the cells and eventually results in oxidative damage to the cell components. ${ }^{42}$ Based on cell viability and cell morphology assay, we assumed that ZnO NPs could affect the intracellular ROS levels in the treated human ovarian cancer cells. Therefore, ROS were assayed using the fluorescent probe DCFH-DA. DCFH-DA fluorescent probe can freely cross the cell membrane and is oxidized to fluorescent DCF by intracellular ROS. The levels of intracellular ROS were quantified by the intensity of DCFH-DA fluorescence (Figure 3A). Compared with the control, the fluorescence intensity was enhanced by comparing with the guidance line as the standard, indicating that the intracellular ROS level was significantly increased. When the ovarian cancer cells were treated with $\mathrm{ZnO}$ NPs for $12 \mathrm{~h}$ at increasing concentrations, fluorescent intensity was increased in the ovarian cancer cells loaded with DCFH-DA probe (Figure 3B). The results demonstrated that the intercellular ROS in the ovarian cells could be upregulated by ZnO NPs. The fluorescence intensity of DCF was increased following exposure to ZnO NPs in a dose-dependent manner. When the astrocytes were treated with various concentrations of $\mathrm{ZnO} N P s$, the ROS level was significantly increased, and also, it increased in a timedependent manner. ${ }^{8,36}$ Recently, Pandurangan et al reported that HeLa cells treated with 0.02 and $0.03 \mathrm{mg} / \mathrm{mL}$ of $\mathrm{ZnO}$ NPs for $48 \mathrm{~h}$ exhibited increased fluorescence intensity of DCF than the control cells, and also that the effect was dose dependent. ${ }^{41}$ Altogether, the results suggest that $\mathrm{ZnO}$ NPs are able to induce ROS generation and eventually lead to oxidative stress. Previously, several studies reported that on using several NPs, including silver, graphene, and palladium, the major cause of cell death was ROS production. ${ }^{43-45}$ Next we examined the effect of ZnO NPs on LDH leakage as the end point of toxicity. The results suggest that leakage of LDH was in a dose-dependent manner, which was substantially consistent with cell viability and generation of ROS (Figure 3C). Similarly, the effect of $\mathrm{ZnO}$ NPs was also observed in mouse testicular cells. ${ }^{29}$ Altogether, all cytotoxicity assays confirmed that $\mathrm{ZnO}$ NPs potentially induce cytotoxicity in human ovarian cancer cells. 

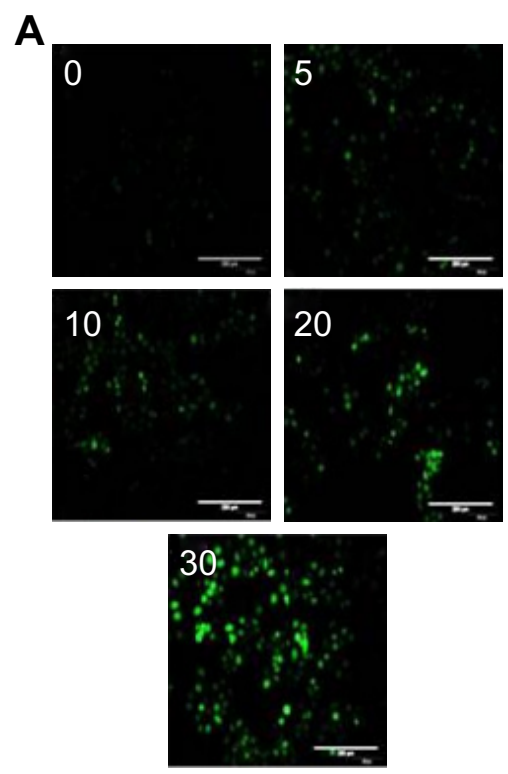

B

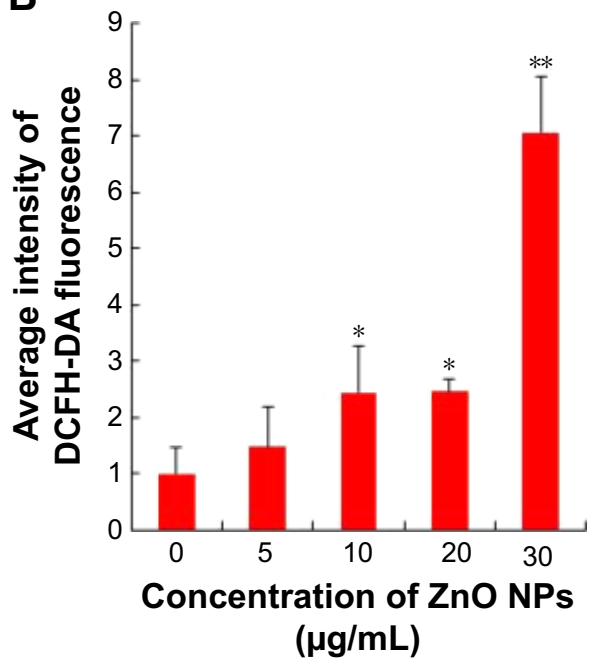

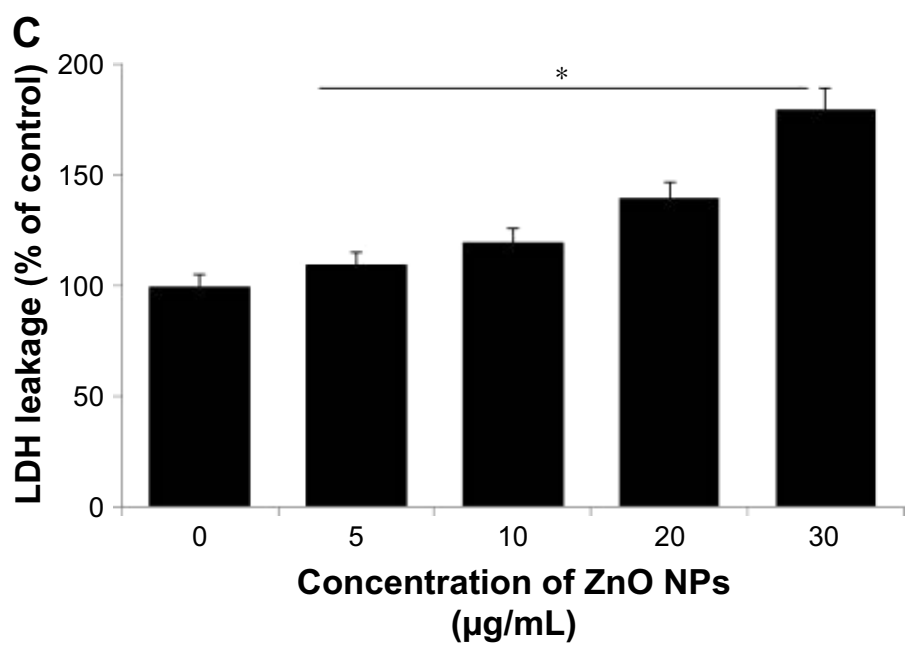

Figure 3 Evaluation of ROS level in SKOV3 cells after ZnO NP treatment.

Notes: (A) Intracellular ROS levels were measured with fluorescence imaging using the DCFH-DA probe in cells cultured in the presence of ZnO NPs (0, 5, I0, 20, and $30 \mu \mathrm{g} / \mathrm{mL}$ ) for $12 \mathrm{~h}$. Scale bars $=200 \mu \mathrm{m}$. (B) The average intensity of fluorescence in SKOV3 cells. The results are expressed as the mean \pm standard deviation of three independent experiments. There was a significant difference in the ROS generation of treated cells compared to that of untreated cells, as assessed using the Student's $t$-test $(* P<0.05 ; * * P<0.01)$. (C) LDH leakage levels were measured in cells cultured in the presence of $\mathrm{ZnO} N \mathrm{Ns}(0,5,10,20$, and $30 \mu \mathrm{g} / \mathrm{mL})$ for $12 \mathrm{~h}$.

Abbreviations: DCFH-DA, dichlorodihydrofluorescein diacetate; LDH, lactate dehydrogenase; ROS, reactive oxygen species; ZnO NPs, zinc oxide nanoparticles.

\section{Mitochondrial dysfunction}

MPT was regulated by a number of factors including reactive oxygen and nitrogen species. ${ }^{46}$ Recent observations in several cancer cells have shown that NPs could enhance the impairment of mitochondria; particularly in mitochondrial membranes, they impaired the ability of a PI3K-like protein kinase (ATR) to induce MPT and the release of apoptogenic proteins. ${ }^{47}$ Thus, we tested the effect of $\mathrm{ZnO}$ NPs on the regulation of MPT caused by enhancement of ROS generation. Healthy cells are known to have intact and functionally active mitochondria which can retain the red JC-1 aggregates, whereas impaired mitochondria could take up green color and exhibit enhanced green JC-1 monomers. As shown in Figure 4A, ZnO NP-exposed cells exhibited a marked impairment of mitochondria in a dose-dependent manner, as evident by a shift in JC-1 florescence from red to green. With increasing concentration of $\mathrm{ZnO}$ NPs, particularly at a higher concentration, the level of JC-1 monomers was significant. ZnO NPs induce cytotoxicity in the human liver cell line HepG2 by increasing the ROS levels and, consequently, causing a decrease in MPT and an increase in the ratio of $\mathrm{Bax} / \mathrm{Bcl}-2 .^{48}$ Human keratinocytes treated with $\mathrm{ZnO}$ NPs induced significant intracellular ROS and mitochondrial ROS production. The increased ROS levels eventually led to 
A
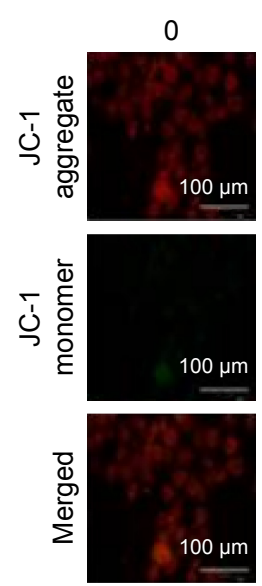

Concentration of $\mathrm{ZnO}$ NPs $(\mu \mathrm{g} / \mathrm{mL})$

5
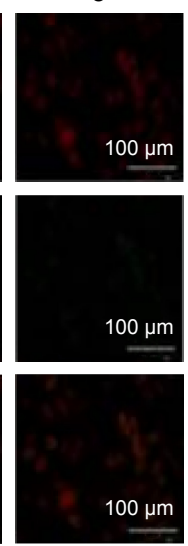

10
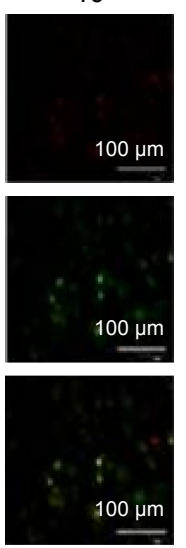

20
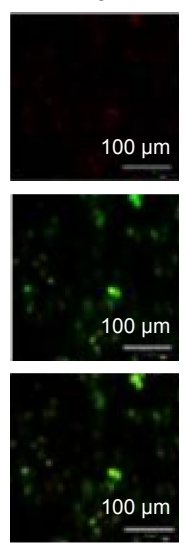

30
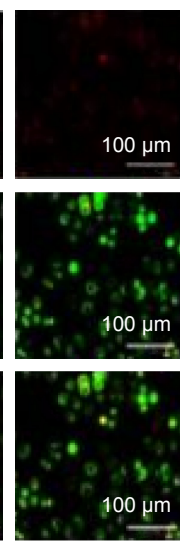

a

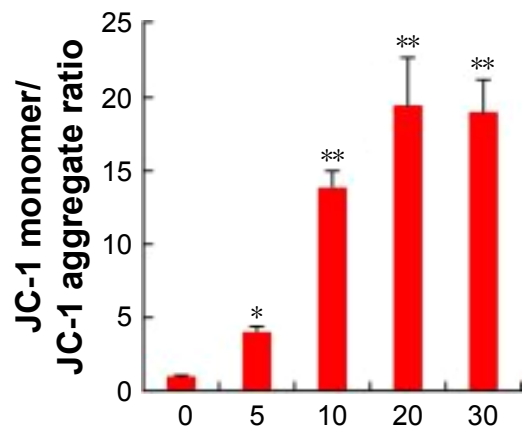

Concentration of ZnO NPs $(\mu \mathrm{g} / \mathrm{mL})$
B
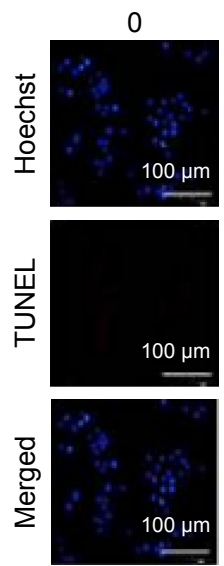

Concentration of $\mathrm{ZnO} \mathrm{NPs}(\mu \mathrm{g} / \mathrm{mL})$
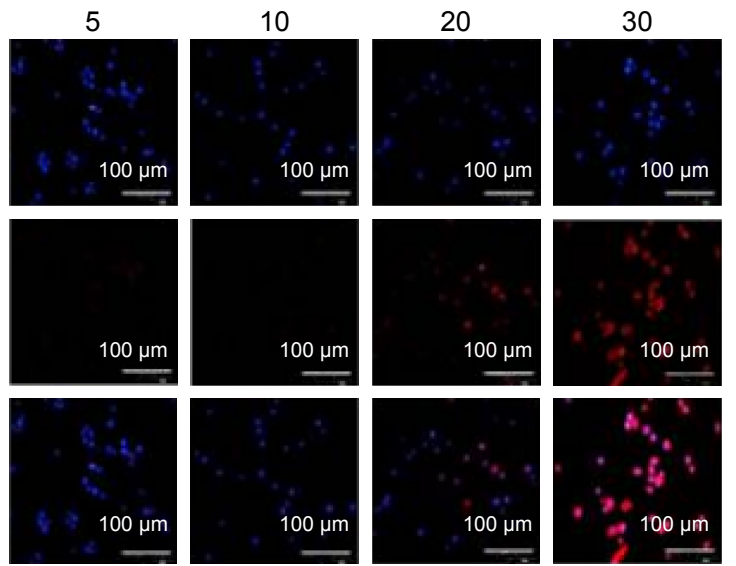

b

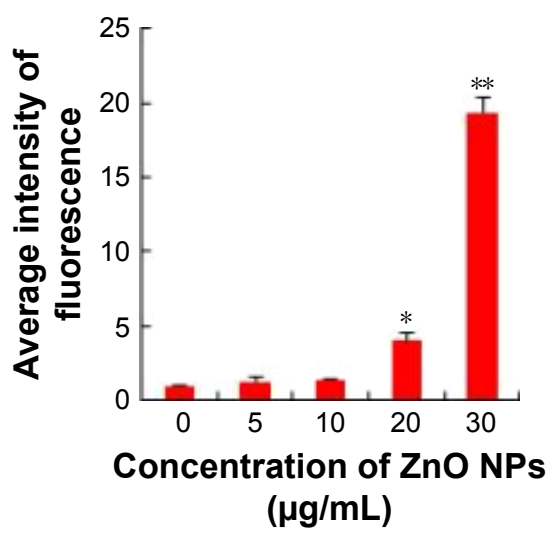

Figure 4 Effects of $\mathrm{ZnO} N P s$ on mitochondrial membrane permeability and apoptosis in SKOV3 cells.

Notes: SKOV3 cells were treated with ZnO NPs $(0,5,10,20$, and $30 \mu g / \mathrm{mL})$ for $12 \mathrm{~h}$. (A) Mitochondrial membrane potential $(\Delta \psi \mathrm{m})$ was evaluated using JC-I in treated cells. Red fluorescence indicates JC-I aggregates within the mitochondria in healthy cells, whereas green fluorescence indicates JC-I monomers in the cytoplasm and loss of $\Delta \psi \mathrm{m}$. Scale bars $=100 \mu \mathrm{m}$. (a) Ratio of JC-I monomers to JC-I aggregated. (B) Apoptosis was assessed in a TUNEL assay; the nuclei were counterstained with DAPI. Representative images show apoptotic (fragmented) DNA (red staining) and the corresponding cell nuclei (blue staining). (b) The average intensity of TUNEL fluorescence in SKOV3. Scale bars $=100 \mu \mathrm{m}$. $* P<0.05 ; * *<<0.01$.

Abbreviations: DAPI, 4',6-diamidino-2-phenylindole; TUNEL, terminal deoxynucleotidyl transferase-mediated dUTP nick end labeling; ZnO NPs, zinc oxide nanoparticles.

the dissipation of the MPT and elicited cellular apoptosis. ${ }^{49}$ Our previous findings also suggest that treatment of mouse testicular cells with ZnO NPs induces loss of MPT. ${ }^{29}$

Following this, we were interested to investigate the influence of ROS, which is a major player for mitochondrial dysfunction. Then we investigated the impact of ROS on the level of apoptosis in ZnO NP-treated ovarian cancer cells using TUNEL assay. ROS consist of free radicals, such as superoxide anion radical $\left(\mathrm{O}_{2}^{-}\right)$, and non-free radicals, including hydrogen peroxide $\left(\mathrm{H}_{2} \mathrm{O}_{2}\right) .{ }^{50}$ With the enrichment of $\mathrm{O}_{2}{ }^{-}$and $\mathrm{H}_{2} \mathrm{O}_{2}$, oxidative stress occurs and the cellular redox balance is impaired, resulting in oxidative damage to cells. ${ }^{51,52}$ ROS at higher levels easily react with membrane lipids, causing an alteration in membrane permeability, and with DNA, causing damage and genomic instability. ${ }^{53}$ Our findings clearly indicated that ZnO NP-treated ovarian cancer cells showed higher level of TUNEL-positive cells, which clearly suggests that the level of ROS was high and the redox balance was impaired, eventually leading to DNA fragmentation (Figure 4B). The DNA profiles of the cells treated with $\mathrm{ZnO}$ NPs for $12 \mathrm{~h}$ along with those of untreated control cells were analyzed. In the control cells, there were no TUNEL-positive cells, whereas the cells treated with ZnO NPs had started the apoptotic process, as was evident from DNA fragmentation analysis. Similarly, ZnO NP-treated human liver cancer HepG2 cells showed remarkable fragmentation of DNA. ${ }^{54}$

Several studies substantially proved that oxidative stress seems to be an important mechanism underlying the toxic effects of metal oxide NPs, using both in vitro and in vivo models. ${ }^{55-58}$ Oxidative stress is definitely caused 
by an imbalance between production of various ROS and antioxidant defense. ROS have been identified as the signaling molecules in various pathways regulating both cell survival and cell death. ${ }^{59-61}$ ROS have dual functions; lower level induces cell signaling for cell survival and higher level causes severe damage to DNA, RNA, and proteins. ${ }^{62,63}$ Our finding and those of previous studies have demonstrated that oxidative stress plays a major role and it is involved in $\mathrm{ZnO}$ NP-induced cytotoxicity in human ovarian cancer cells.

\section{ZnO NPs induce DNA double-strand breaks}

Metal NPs are able to induce oxidative stress within cells, which often results in DNA damage. ${ }^{19,64,65}$ Therefore, ROS formation and DNA damage in treated human ovarian cancer cells were analyzed to investigate their possible involvement in the induction of DNA damage. DNA double-strand breaks (DSBs) are one of the most toxic of these lesions and must be repaired to preserve chromosomal integrity. ${ }^{66}$ DNA damage can occur as a result of endogenous metabolic reactions and replication stress or from exogenous sources such as radiation, chemotherapeutics, or NPs. ${ }^{66} \mathrm{ZnO}$ NPs induced double-strand DNA fragmentation was studied using $\gamma$-H2AX staining. Phosphorylation of the core histone variant $\mathrm{H} 2 \mathrm{AX}(\gamma-\mathrm{H} 2 \mathrm{AX})$, a suitable marker of DNA damage-induced histone modification, serves as a hallmark of DNA DSBs. ${ }^{67-69}$ Therefore, we measured the distribution of $\gamma$-H2AX in the nucleus after exposure to $\mathrm{ZnO}$ NPs for $12 \mathrm{~h}$ (Figure 5A). The phosphorylation of histone $\mathrm{H} 2 \mathrm{AX}$ (a marker of DNA DSBs) was analyzed according to the method described previously. ${ }^{70}$ The immunofluorescent images of histone $\mathrm{H} 2 \mathrm{AX}$ phosphorylation in $\gamma$-H2AX-stained human ovarian cancer cells are shown in Figure 5A. The immunostaining results showed that the $\gamma$-H2AX signals were increased significantly in treated samples compared with controls and that the signals were dispersed throughout the whole nucleus after treatment with 10,20 , and $30 \mu \mathrm{g} / \mathrm{mL}$, whereas the signals were stronger after treatment with $30 \mu \mathrm{g} / \mathrm{mL}$ (Figure 5A). Treatment with $\mathrm{ZnO}$ NPs resulted in a dose-dependent induction of $\gamma-\mathrm{H} 2 \mathrm{AX}$ foci. In the control group, ovarian cancer cells had no $\gamma$-H2AX foci in the nuclei. It was concluded that increasing concentration of $\mathrm{ZnO}$ NPs induced foci formation and increased the percentage of $\gamma$-H2AX-positive cells. As shown in Figure 5A, ZnO NPs exhibited distinct concentration-dependent effects $(P<0.01)$ on $\gamma$-H2AX foci formation in human ovarian cancer cells. The accumulation of $\gamma$-H2AX signals indicated that DNA breaks had occurred and that the damage exacerbated with higher concentrations of $\mathrm{ZnO}$ NPs, consistent with a previous report that observed increased $\gamma$-H2AX signals in cultured (CHO)-K1 cells and human epidermal keratinocytes after exposure to increasing concentrations of $\mathrm{ZnO}$ NPs. ${ }^{71,72}$

Next we examined the effect of double-strand DNA breaks using another tool, Rad51 antibody. Rad51 is a DNA-dependent ATPase that forms a filament on ssDNA and promotes strand invasion with a homologous doublestranded partner. ${ }^{66}$ When the ovarian cancer cells were treated with ZnO NPs, it led to an increase in Rad51 foci formation after $12 \mathrm{~h}$ of treatment. More pronounced foci formation was observed with $20 \mu \mathrm{g} / \mathrm{mL}$ treatment than with a concentration of $30 \mu \mathrm{g} / \mathrm{mL}$. Although we used the same NPs for DSBs using $\gamma$-H2AX and Rad51 antibodies, H2AX highly responded to $30 \mu \mathrm{g} / \mathrm{mL}$ and $\operatorname{Rad} 51$ to $20 \mu \mathrm{g} / \mathrm{mL}$ concentration. $\operatorname{Rad} 51$ foci appeared in more micronuclei $12 \mathrm{~h}$ after exposure than $\gamma$-H2AX foci. Although Rad51 foci may only mark a subset of the DSBs, the number of residual Rad51 foci per cell was invariably higher than the number of residual $\gamma$-H2AXX foci (Figure 5A and B). This study found that ZnO NPs inhibited growth of ovarian cancer cells through induction of apoptosis and DNA damage in vitro. Furthermore, $\mathrm{ZnO}$ NPs were found to induce apoptosis and DNA damage of ovarian cancer cells in a dose-dependent manner. Therefore, ZnO NPs act as a potent genotoxin by inducing marked accumulation of DNA DSBs. The results indicate that treatment with ZnO NPs triggers a cascade that includes DNA damage.

\section{$\mathrm{ZnO}$ NPs induce apoptosis and autophagy by activation of $\mathrm{p} 53$ and LC3 expression}

p53 is a key player for determining a multitude of important cellular responses that may vary from protecting the integrity of the genome, inducing apoptosis, regulating glycolysis and autophagy, to even promoting cell differentiation. ${ }^{73}$ Apoptosis is mainly regulated by $\mathrm{p} 53$, particularly by the intrinsic mitochondrial or extrinsic death receptor pathway. ${ }^{74}$ Therefore, in this study, the expression of tumor suppressor protein $\mathrm{p} 53$ was examined to correlate the DNA damaging potential of $\mathrm{ZnO}$, as shown in previous experiments. The results revealed that the cells treated with $\mathrm{ZnO}$ NPs showed increased number of $\mathrm{p} 53$ positive cells compared to control. We observed a significant $(P<0.05)$ dose-dependent increase in the expression of tumor suppressor protein p53 in ovarian cancer cells treated with $\mathrm{ZnO}$ NPs at concentrations of 10,20 , and $30 \mu \mathrm{g} / \mathrm{mL}$ for $12 \mathrm{~h}$ (Figure 6A). These results demonstrated that $\mathrm{ZnONP-induced}$ tumor suppressor gene expression can inhibit proliferation of ovarian cancer cell remarkably, providing new strategy for 
A
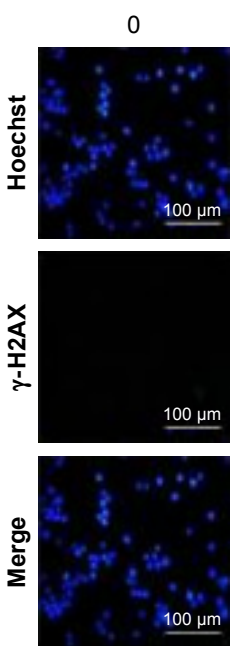

B
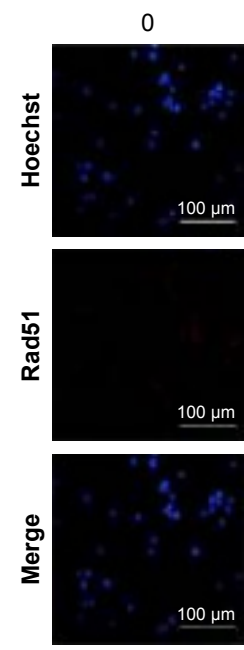

Concentration of $\mathrm{ZnO}$ NPs ( $\mu \mathrm{g} / \mathrm{mL}$ )
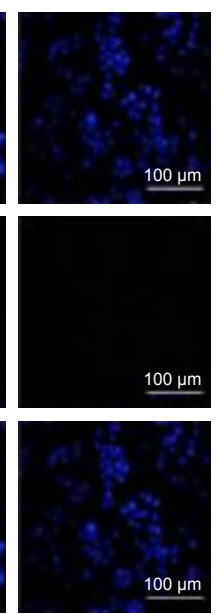

10

20
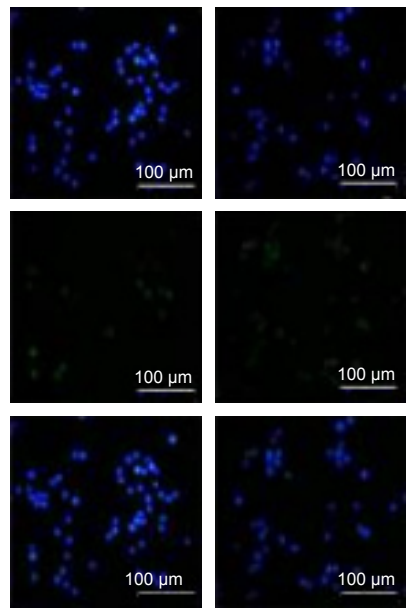

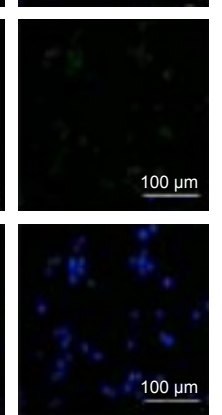

$100 \mu \mathrm{m}$
Concentration of ZnO NPs ( $\mu \mathrm{g} / \mathrm{mL}$ )
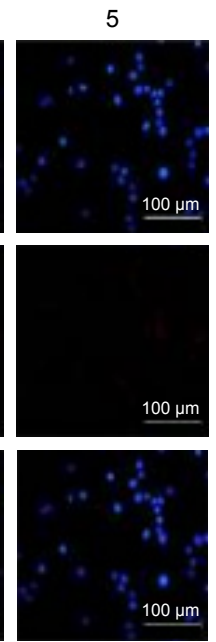

10
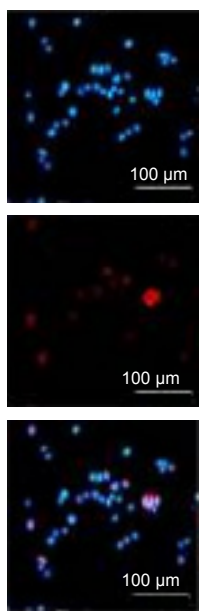
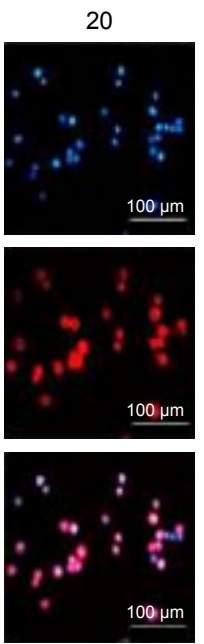

30
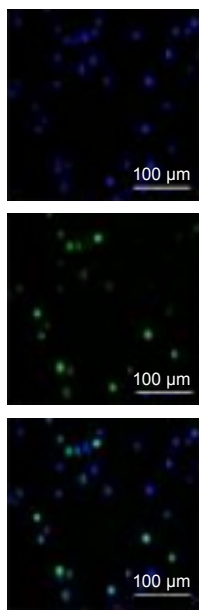

30

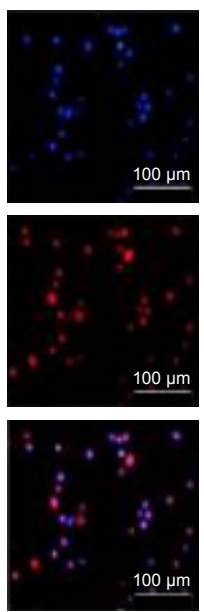

a

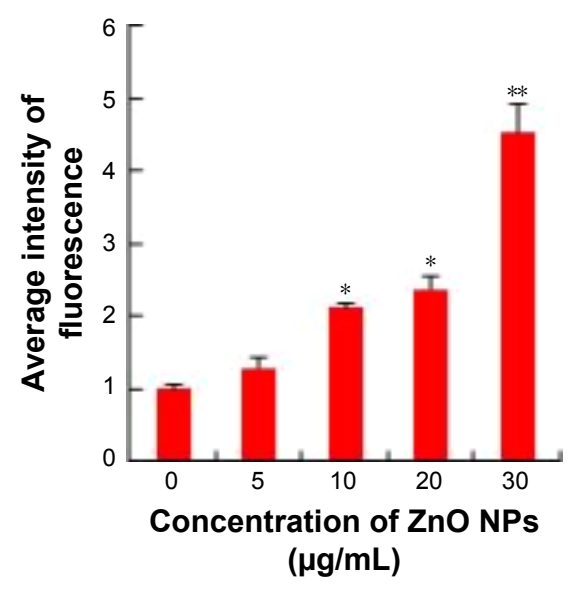

b

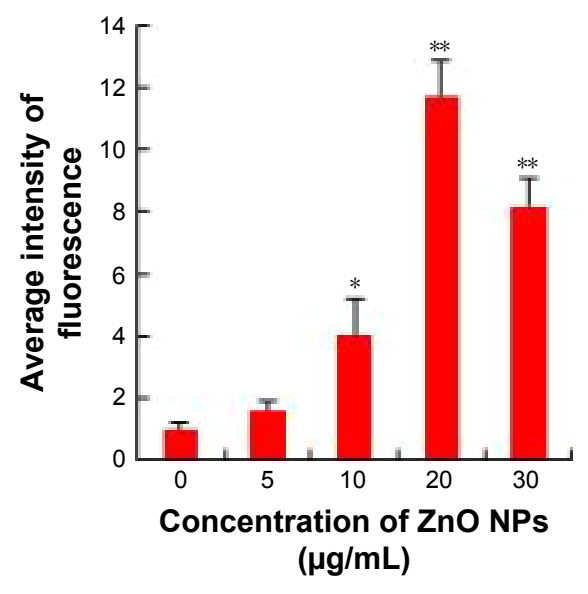

Figure 5 Nuclear DNA damage in SKOV3 cells after ZnO NP treatment using immunocytofluorescense with $\gamma$ - $\mathrm{H} 2 \mathrm{AX}$ and Rad5I antibody.

Notes: (A) Nuclear $\gamma$-H2AX foci in cells in vitro exposed to $\mathrm{ZnO} N P s(0,5,10,20$, and $30 \mu \mathrm{g} / \mathrm{mL})$ for $12 \mathrm{~h}$. The results are expressed as the mean \pm standard deviation of three separate experiments. (a) The average intensity of $\gamma-\mathrm{H} 2 \mathrm{AX}$ fluorescence in SKOV3. Scale bars $=100 \mu \mathrm{m}$. (B) Nuclear Rad5I foci in cells in vitro exposed to ZnO NPs $(0,5,10,20$, and $30 \mu \mathrm{g} / \mathrm{mL})$ for $12 \mathrm{~h}$. The results are expressed as the mean \pm standard deviation of three separate experiments. (b) The average intensity of Rad5I fluorescence in SKOV3. Scale bars $=100 \mu \mathrm{m}$. $* P<0.05 ; * * P<0.01$.

Abbreviation: $\mathrm{ZnO}-\mathrm{NPs}$, zinc oxide nanoparticles.

cancer therapy. The p53 pathway is extremely sensitive to a very small number of DNA strand breaks or single-stranded gaps. This can also be considered as a factor that could be important in the early detection of DNA lesions in tumors. The activation of p53 is able to control many biologic processes including growth arrest and apoptosis. ${ }^{75,76}$ The expression profile of p53 protein was significant, which supports the DNA damaging potential of the ZnO NPs.

Previously, several studies in tumor cells have shown that the p53 tumor suppressor protein, which is an important cellular stress sensor, can trigger cell cycle arrest and apoptosis and also regulate autophagy. ${ }^{77-80}$ In addition, p53 appears to play a dual role in the control of autophagy. At basal levels, p53 has an inhibitory effect and its activation initiates the autophagic process. ${ }^{78,81}$ Thus, we examined the effect of $\mathrm{ZnO}$ NPs on LC3 expression in ovarian cancer cells. In this study, the effects of ZnO NPs on autophagy were investigated in $\mathrm{ZnO}$ NP-treated cells via fluorescence microscopy using an LC3 antibody to detect LC3-II/-I expression and Hoechst 33258 to assess nuclear morphology. Visualization of LC3 immunofluorescence revealed remarkable detectable fluorescence in the $\mathrm{ZnO}$ NP-treated cells, whereas there was no detectable fluorescence in the control cells. However, the fluorescence was observed at a 
A
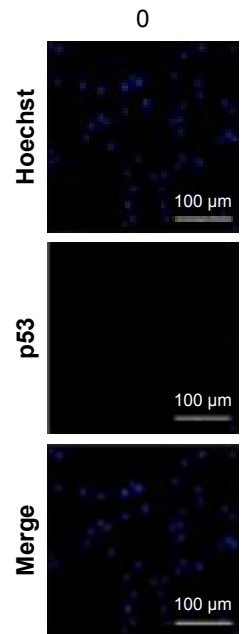

B
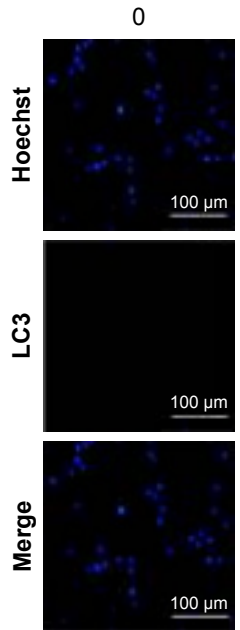

Concentration of $\mathrm{ZnO}$ NPs $(\mu \mathrm{g} / \mathrm{mL})$

10
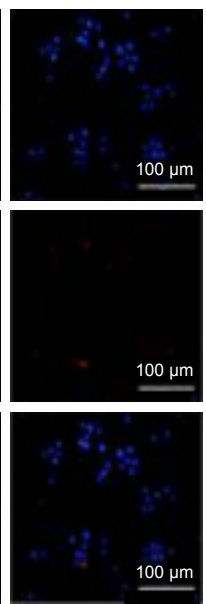

Concentration of ZnO NPs $(\mu \mathrm{g} / \mathrm{mL})$
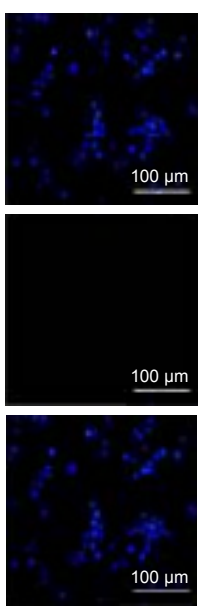

10

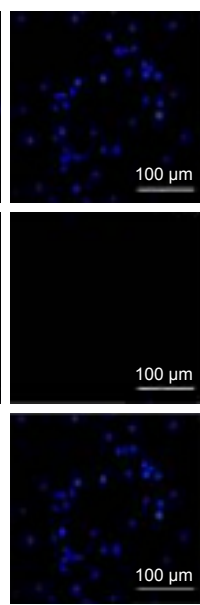

20
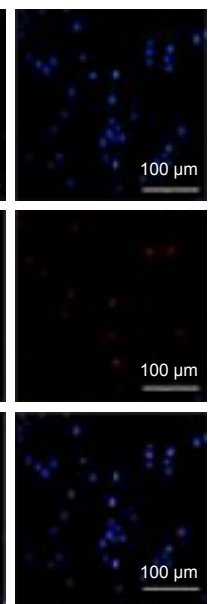

$100 \mu \mathrm{m}$
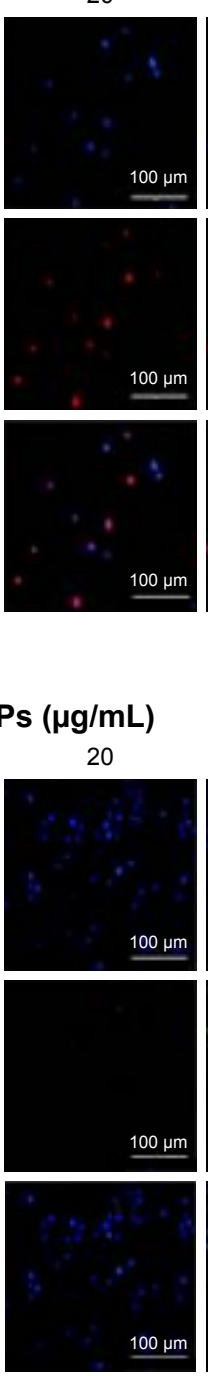

30

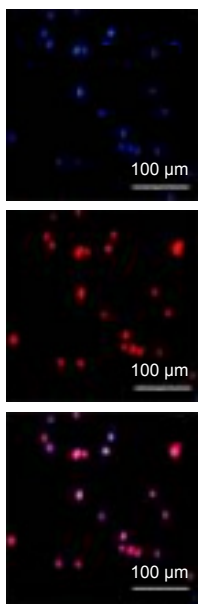

30

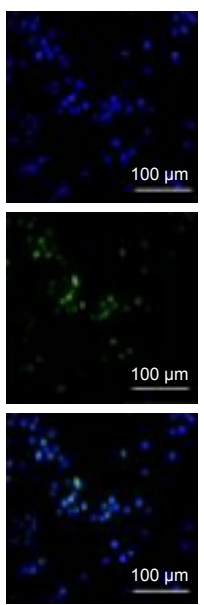

a

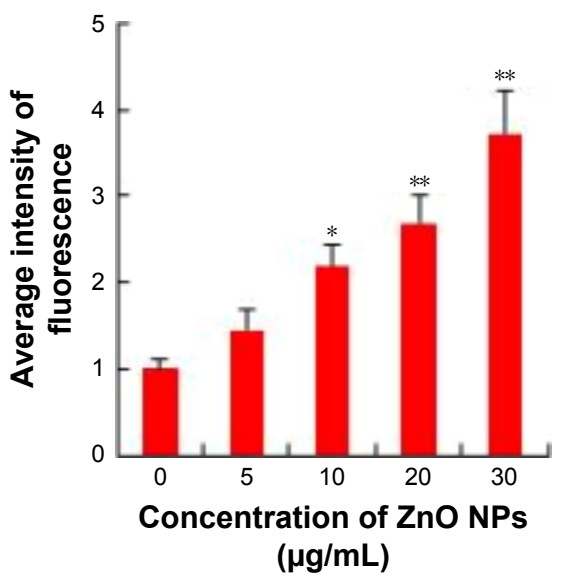

b

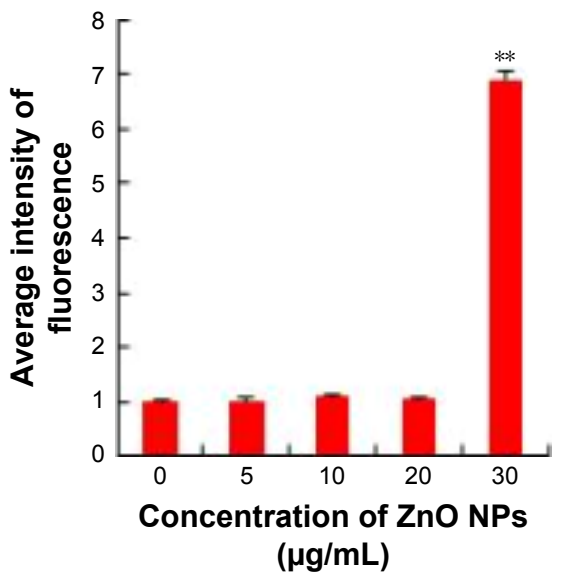

Figure $6 \mathrm{ZnO}$ NP exposure increases apoptosis and autophagy in cultured SKOV3 cells in $12 \mathrm{~h}$.

Notes: The cells were treated with ZnO NPs $(0,5,10,20$, and $30 \mu \mathrm{g} / \mathrm{mL})$ for $12 \mathrm{~h}$ and then processed for immunofluorescence analysis. (A) p53-stained SKOV3: (a) the average intensity of $\mathrm{p} 53$ fluorescence in SKOV3. Scale bars $=100 \mu \mathrm{m}$. (B) LC3-stained SKOV3: (b) the average intensity of LC3 fluorescence in SKOV3. Scale bars =100 $\mu \mathrm{m}$. $* P<0.05 ; * * P<0.01$.

Abbreviation: ZnO NPs, zinc oxide nanoparticles.

higher concentration only, but not in lower concentration (Figure 6B). Quantitative analysis revealed significant difference in treated cells when compared to the control group. Consistent with our findings, ZnO NPs induced autophagic cell death and mitochondrial damage via ROS generation in JB6 Cl 41-5a mouse skin epidermal normal cells. ${ }^{82}$ The results suggest that activation of autophagy may promote or inhibit apoptosis, depending on the level of the insult caused by $\mathrm{ZnO}$ NPs.

\section{Activation of signaling molecules involved in apoptotic and autophagy}

Next we examined the mechanism of cell death caused by $\mathrm{ZnO}$ NPs using Western blot analysis by activation/deactivation of certain crucial components in the cellular system. The expression of apoptosis-related proteins such as Bax, Bcl-2, caspase-9, Rad51, $\gamma$-H2AX, p53, and LC3 was examined by Western blotting analysis (Figure 7). All marker protein levels were increased, except antiapoptotic protein $\mathrm{Bcl}-2$, consistent with its well-known downregulation of apoptotic process, whereas all other proteins were upregulated. In the presence of DNA damage or cellular stress, p53 triggers cell cycle arrest to provide time for the damage to be repaired or for self-mediated apoptosis. ${ }^{83,54}$ The activation of $\mathrm{p} 53$ could be the possible regulator for upregulation of Bax. Cleavage of DNA at the internucleosomal linker sites yielding DNA fragments is regarded as a biochemical hallmark of apoptosis. ${ }^{84}$ Enhanced expression level of caspase-9 leads to rapid and 


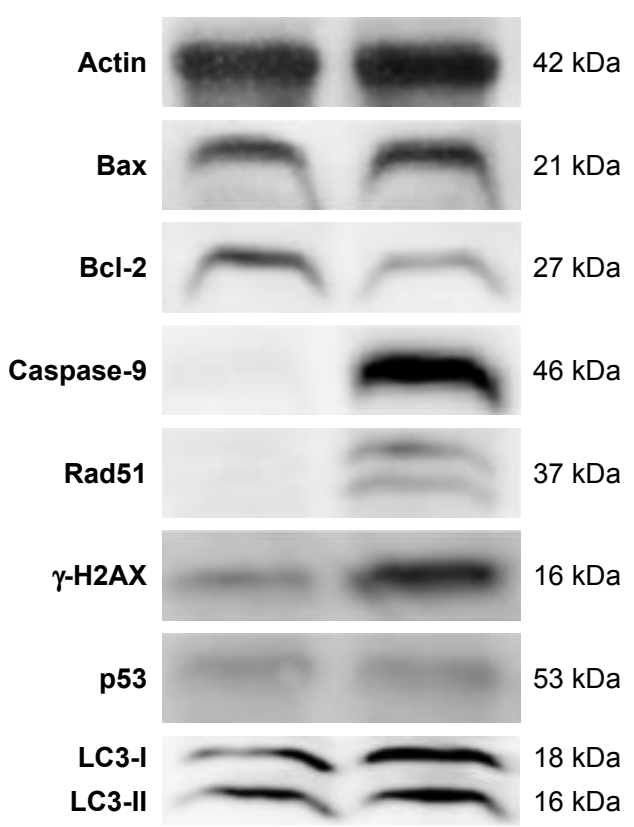

Figure 7 Assessment by Western blotting.

Notes: The SKOV 3 cells were treated with ZnO NPs $(30 \mu \mathrm{g} / \mathrm{mL})$ for $12 \mathrm{~h}$ and the expression analysis of $\mathrm{Bax}, \mathrm{Bcl}-2$, caspase-9, $\operatorname{Rad} 5 \mathrm{I}, \gamma-\mathrm{H} 2 \mathrm{AX}, \mathrm{LC} 3$, and $\mathrm{p} 53$ was performed by Western blot analysis. Data are presented from three independent experiments.

Abbreviation: $\mathrm{ZnO}$ NPs, zinc oxide nanoparticles.

irreversible apoptosis. This study demonstrates that $\mathrm{ZnO}$ NPs treated ovarian cancer cells showed high level expression caspase-9 and significant level of DNA fragmentation causes apoptosis. Consistent with our findings, Akhtar et al reported that the protein levels of $\mathrm{p} 53$ and bax were significantly upregulated, while the expression of bcl-2 was significantly downregulated in $\mathrm{ZnO}$ NP-treated human lung cancer (HepG2) cells. ${ }^{54}$ Furthermore, the cells treated with $\mathrm{ZnO}$ NPs showed significant expression of $\gamma$-H2AX and Rad51 than the control group, which is also consistent with immunofluorescence data. Altogether, the results showed that $\mathrm{ZnO} \mathrm{NP}$-induced ROS generation is responsible for mitochondrial-mediated apoptosis and autophagy-induced apoptosis. Exposure of human ovarian cancer cells to $\mathrm{ZnO}$ NPs resulted in autophagic death and increased levels of LC3, an essential component of autophagic vacuoles. Johnson et al demonstrated that $\mathrm{ZnO}$ NPs induce cell death in immune cells via enhanced expression of LC3A. ${ }^{85} \mathrm{Yu}$ et al provided substantial evidence for $\mathrm{ZnO}$ NP-induced autophagy, in which ZnO NPs significantly increased LC3-positive dots and also the expression of autophagy-related proteins (BECN1 and LC3) was significantly increased in JB6 Cl 41-5a mouse skin epidermal normal cells. ${ }^{82}$ Altogether, these findings suggest that $\mathrm{ZnO}$ NPs lead to cell death through apoptosis and autophagy and also mitochondrial damage via ROS induction.

\section{Conclusion}

In this study, we demonstrated that $\mathrm{ZnO}$ NPs with an average size of $20 \mathrm{~nm}$ are able to induce significant cytotoxicity to human ovarian cancer cells via induction of intracellular ROS through which they could directly affect a mechanical pathway of cell viability by apoptosis and autophagy, cause mitochondrial disruption, and alteration of MPT and function. Particularly, ZnO NPs could interact with DNA and induce DNA fragmentation and double-strand DNA breaks and eventually lead to cell death. Further, this study clearly demonstrated that the induction of apoptosis is directly associated with the genotoxicity of $\mathrm{ZnO}$ NPs. The mechanisms underlying the genotoxicity of $\mathrm{ZnO}$ NPs require further investigation to clearly demonstrate that $\mathrm{ZnO}$ NPs cause genotoxicity and apoptosis. Further studies are required to understand the biologic consequences of DNA damage on exposure to $\mathrm{ZnO}$ NPs and induction of autophagy.

\section{Acknowledgments}

This study was supported by the KU-Research Professor Program of Konkuk University and by the Science and Technology Research Program of the Department of Education of Hubei Province, People's Republic of China (D20151701).

\section{Disclosure}

The authors report no conflicts of interest in this work.

\section{References}

1. Zhao J, Castranova V. Toxicology of nanomaterials used in nanomedicine. J Toxicol Environ Health B Crit Rev. 2011;14(8):593-632.

2. Becheri A, Dürr M, Nostro PL, Baglioni P. Synthesis and characterization of zinc oxide nanoparticles: application to textiles as UV-absorbers. J Nanopart Res. 2008;10(4):679-689.

3. Rasmussen JW, Martinez E, Louka P, Wingett DG. Zinc oxide nanoparticles for selective destruction of tumor cells and potential for drug delivery applications. Expert Opin Drug Del. 2010;7(9): 1063-1077.

4. Hanley C, Layne J, Punnoose A, et al. Preferential killing of cancer cells and activated human $\mathrm{T}$ cells using $\mathrm{ZnO}$ nanoparticles. Nanotechnology. 2008;19(29):295103.

5. Wang H, Wick RL, Xing B. Toxicity of nanoparticulate and bulk $\mathrm{ZnO}, \mathrm{A} 12 \mathrm{O} 3$ and $\mathrm{TiO} 2$ to the nematode Caenorhabditis elegans. Environ Pollut. 2009;157(4):1171-1177.

6. Smalley KS, Herlyn M. Towards the targeted therapy of melanoma. Mini Rev Med Chem. 2006;6(4):387-393.

7. McNeil SE. Nanoparticle therapeutics: a personal perspective. Wiley Interdiscip Rev Nanomed Nanobiotechnol. 2009;1(3):264-271.

8. Wang X, Wang W, Li L, Perry G, Lee HG, Zhu X. Oxidative stress and mitochondrial dysfunction in Alzheimer's disease. Biochim Biophys Acta. 2014;1842(8):1240-1247.

9. Unfried K, Albrecht C, Klotz LO, von Mikecz A, Grether-Beck S, Schins RPF. Cellular responses to nanoparticles: target structures and mechanisms. Nanotoxicology. 2007;1(1):52-71.

10. Wood A, Schneider J, Shilatifard A. Cross-talking histones: implications for the regulation of gene expression and DNA repair. Biochem Cell Biol. 2005;83(4):460-467. 
11. Pati R, Das I, Mehta RK, Sahu R, Sonawane A. Zinc-oxide nanoparticles exhibit genotoxic, clastogenic, cytotoxic and actin depolymerization effects by inducing oxidative stress responses in macrophages and adult mice. Toxicol Sci. 2016;150(2):454-472.

12. Gottlieb E, Armour SM, Harris MH, Thompson CB. Mitochondrial membrane potential regulates matrix configuration and cytochrome $\mathrm{c}$ release during apoptosis. Cell Death Differ. 2003;10(6):709-717.

13. Mathew R, White E. Autophagy in tumorigenesis and energy metabolism: friend by day, foe by night. Curr Opin Genet Dev. 2011;21(1): 113-119.

14. Turcotte S, Chan DA, Sutphin PD, Hay MP, Denny WA, Giaccia AJ. A molecule targeting VHL-deficient renal cell carcinoma that induces autophagy. Cancer Cell. 2008;14(1):90-102.

15. Pandurangan M, Kim DH. A novel approach for in vitro meat production. Appl Microbiol Biotechnol. 2015;99(13):5391-5395.

16. George S, Pokhrel S, Xia T, et al. Use of a rapid cytotoxicity screening approach to engineer a safer zinc oxide nanoparticle through iron doping. ACS Nano. 2010;4(1):15-29.

17. Ng KW, Khoo SP, Heng BC, et al. The role of the tumor suppressor p53 pathway in the cellular DNA damage response to zinc oxide nanoparticles. Biomaterials. 2011;32(32):8218-8225.

18. Palomäki J, Karisola P, Pylkkänen L, Savolainen K, Alenius H. Engineered nanomaterials cause cytotoxicity and activation on mouse antigen presenting cells. Toxicology. 2010;267(1-3):125-131.

19. Sharma V, Shukla RK, Saxena N, Parmar D, Das M, Dhawan A. DNA damaging potential of zinc oxide nanoparticles in human epidermal cells. Toxicol Lett. 2009;185(3):211-218.

20. Valdiglesias V, Costa C, Kiliç G, et al. Neuronal cytotoxicity and genotoxicity induced by zinc oxide nanoparticles. Environ Int. 2013;55: 92-100.

21. Dhanasekaran DN, Reddy EP. JNK signaling in apoptosis. Oncogene. 2008;27(48):6245-6251.

22. Lai JC, Lai MB, Jandhyam S, et al. Exposure to titanium dioxide and other metallic oxide nanoparticles induces cytotoxicity on humanneural cells and fibroblasts. Int J Nanomedicine. 2008;3(4):533-545.

23. Liu S, Xu L, Zhang T, Ren G, Yang Z. Oxidative stress and apoptosis induced by nanosized titanium dioxide in PC12 cells. Toxicology. 2010;267(1-3):172-177.

24. Gurunathan S, Park JH, Han JW, Kim JH. Comparative assessment of the apoptotic potential of silver nanoparticles synthesized by Bacillus tequilensis and Calocybe indica in MDA-MB-231 human breast cancer cells: targeting p53 for anticancer therapy. Int J Nanomedicine. 2015;10:4203-4222.

25. Jin BJ, Bae SH, Lee SY, Im S. Effects of native defects on optical and electrical properties of $\mathrm{ZnO}$ prepared by pulsed laser deposition. Mater Sci Eng B. 2000;71(1-3):301-305.

26. Zhang XT, Liu YC, Zhang LG, et al. Structure and optically pumped lasing from nanocrystalline $\mathrm{ZnO}$ thin films prepared by thermal oxidation of ZnS thin films. J Appl Phys. 2002;92(6):3293-3298.

27. Talam S, Karumuri SR, Gunnam N. Synthesis, characterization, and spectroscopic properties of $\mathrm{ZnO}$ nanoparticles. ISRN Nanotechnology. 2012;2012: Article ID 372505.

28. Nagarajan S, Arumugam Kuppusamy K. Extracellular synthesis of zinc oxide nanoparticle using seaweeds of gulf of Mannar, India. J Nanobiotechnology. 2013;11:39.

29. Han Z, Yan Q, Ge W, et al. Cytotoxic effects of $\mathrm{ZnO}$ nanoparticles on mouse testicular cells. Int J Nanomedicine. 2016;11:5187-5203.

30. Khoshhesab ZM, Sarfaraz M, Asadabad MA. Preparation of ZnO nanostructures by chemical precipitation method. Synth React Inorg Metal Org Nano Metal Chem. 2011;41(7):814-819.

31. Markova-Deneva I. Infrared spectroscopy investigation of metallic nanoparticles based on copper, cobalt, and nickel synthesized through borohydride reduction method. J University Chem Tech Met. 2010; 45(4):351-378.

32. Kumar H, Rani R. Structural and optical characterization of zinc oxide nanoparticles synthesized by microemulsion. Int Lett Chem Phy Astro. 2013;14:26-36
33. Sutradhar P, Saha M. Green synthesis of zinc oxide nanoparticles using tomato extract and its photovoltaic application. J Exp Nanosci. 2015; 11(5):314-327.

34. Eita M, El Sayed R, Muhammed M. Optical properties of thin films of zinc oxide quantum dots and polydimethylsiloxane: UV-blocking and the effect of cross-linking. J Colloid Interface Sci. 2012;387(1):135-140.

35. Lee SH, Lee HR, Kim YR, Kim MK. Toxic response of zinc oxide nanoparticles in human epidermal keratinocyte HaCaT cells. Toxicol Envir Health Sci. 2012;4(1):14-18.

36. Wang $\mathrm{C}, \mathrm{Hu} \mathrm{X}, \mathrm{Gao} \mathrm{Y}, \mathrm{Ji} \mathrm{Y}$. ZnO nanoparticles treatment induces apoptosis by increasing intracellular ROS levels in LTEP-a-2 cells. Biomed Res Int. 2015;2015:423287.

37. Chuang KJ, Lee KY, Pan CH, et al. Effects of zinc oxide nanoparticles on human coronary artery endothelial cells. Food Chem Toxicol. 2016; 93:138-144.

38. Syama S, Reshma SC, Sreekanth PJ, Varma HK, Mohanan PV. Effect of zinc oxide nanoparticles on cellular oxidative stress and antioxidant defense mechanisms in mouse liver. Toxicol Environ Chem. 2013; 95(3):495-503.

39. Wang J, Deng X, Zhang F, Chen D, Ding W. ZnO nanoparticle-induced oxidative stress triggers apoptosis by activating JNK signaling pathway in cultured primary astrocytes. Nanoscale Res Lett. 2014;9(1):117.

40. Wang $\mathrm{C}, \mathrm{Hu} \mathrm{X}$, Gao Y, Ji Y. ZnO nanoparticles treatment induces apoptosis by increasing intracellular ROS levels in LTEP-a-2 cells. Biomed Res Int. 2015;2015:423287.

41. Pandurangan M, Enkhtaivan G, Kim DH. Anticancer studies of synthesized $\mathrm{ZnO}$ nanoparticles against human cervical carcinoma cells. J Photochem Photobiol B. 2016;158:206-211.

42. Carmody RJ, Cotter TG. Signalling apoptosis: a radical approach. Redox Rep. 2001;6(2):77-90.

43. Gurunathan S, Han JW, Park JH, et al. Reduced graphene oxide-silver nanoparticle nanocomposite: a potential anticancer nanotherapy. Int $J$ Nanomedicine. 2015;10:6257-6276.

44. Gurunathan S, Han J, Park JH, Kim JH. An in vitro evaluation of graphene oxide reduced by Ganoderma spp. in human breast cancer cells (MDA-MB-231). Int J Nanomedicine. 2014;9:1783-1797.

45. Gurunathan S, Kim E, Han JW, Park JH, Kim JH. Green chemistry approach for synthesis of effective anticancer palladium nanoparticles. Molecules. 2015;20(12):22476-22498.

46. Vieira HL. Adenine nucleotide translocator mediates the mitochondrial membrane permeabilization induced by lonidamine, arsenite and CD437. Oncogene. 2001;20(52):7579.

47. Colell A, García-Ruiz C, Lluis JM, Coll O, Mari M, Fernández-Checa JC. Cholesterol impairs the adenine nucleotide translocator-mediated mitochondrial permeability transition through altered membrane fluidity. J Biol Chem. 2003;278(36):33928-33935.

48. Sharma V, Shaheen SS, Dixit D, Sen E. Farnesyltransferase inhibitor manumycin targets IL1 $\beta$-Ras-HIF- $1 \alpha$ axis in tumor cells of diverse origin. Inflammation. 2012;35(2):516-519.

49. Ryu DS, Kim SH, Kwon JH, Lee DS. Orostachys japonicus induces apoptosis and cell cycle arrest through the mitochondria-dependent apoptotic pathway in AGS human gastric cancer cells. Int $J$ Oncol. 2014;45(1):459-469.

50. Spitz DR, Azzam EI, Li JJ, Gius D. Metabolic oxidation/reduction reactions and cellular responses to ionizing radiation: a unifying concept in stress response biology. Cancer Metastasis Rev. 2004;23(3-4): 311-322.

51. Fiers W, Beyaert R, Declercq W, Vandenabeele P. More than one way to die: apoptosis, necrosis and reactive oxygen damage. Oncogene. 1999; 18(54):7719-7730.

52. Jones DP. Radical-free biology of oxidative stress. Am J Physiol Cell Physiol. 2008;295(4):C849-C868.

53. Barrera G. Oxidative stress and lipid peroxidation products in cancer progression and therapy. ISRN Oncol. 2012;2012:137289.

54. Akhtar MJ, Ahamed M, Kumar S, Khan MM, Ahmad J, Alrokayan SA. Zinc oxide nanoparticles selectively induce apoptosis in human cancer cells through reactive oxygen species. Int J Nanomedicine. 2012;7:845-857. 
55. Shukla RK, Sharma V, Pandey AK, Singh S, Sultana S, Dhawan A. ROS-mediated genotoxicity induced by titanium dioxide nanoparticles in human epidermal cells. Toxicol In Vitro. 2011;25(1):231-241.

56. Guo D, Bi H, Liu B, Wu Q, Wang D, Cui Y. Reactive oxygen speciesinduced cytotoxic effects of zinc oxide nanoparticles in rat retinal ganglion cells. Toxicol In Vitro. 2013;27(2):731-738.

57. Sharma V, Anderson D, Dhawan A. Zinc oxide nanoparticles induce oxidative DNA damage and ROS-triggered mitochondria mediated apoptosis in human liver cells (HepG2). Apoptosis. 2012;17(8):852-870.

58. Gurunathan S, Raman J, Abd Malek SN, John PA, Vikineswary S. Green synthesis of silver nanoparticles using Ganoderma neo-japonicum Imazeki: a potential cytotoxic agent against breast cancer cells. Int J Nanomedicine. 2013;8:4399-4413.

59. Wu D, Zhai Q, Shi X. Alcohol-induced oxidative stress and cell responses. J Gastroenterol Hepatol. 2006;21(3):S26-S29.

60. Azad MB, Chen Y, Gibson SB. Regulation of autophagy by reactive oxygen species (ROS): implications for cancer progression and treatment. Antioxid Redox Signal. 2009;11(4):777-790.

61. Limón-Pacheco J, Gonsebatt ME. The role of antioxidants and antioxidant-related enzymes in protective responses to environmentally induced oxidative stress. Mutat Res. 2009;674(1-2):137-147.

62. Brigelius-Flohé R. Commentary: oxidative stress reconsidered. Genes Nutr. 2009;4(3):161-163.

63. Dayem AA, Choi HY, Kim JH, Cho SG. Role of oxidative stress in stem, cancer, and cancer stem cells. Cancers (Basel). 2010;2(2):859-884

64. Sharma V, Singh P, Pandey AK, Dhawan A. Induction of oxidative stress, DNA damage and apoptosis in mouse liver after sub-acute oral exposure to zinc oxide nanoparticles. Mutat Res. 2012;745(1-2):84-91.

65. Gao F, Ma N, Zhou H, et al. Zinc oxide nanoparticles-induced epigenetic change and G2/M arrest are associated with apoptosis in human epidermal keratinocytes. Int J Nanomedicine. 2016;11:3859-3874.

66. Mehta A, Haber JE. Sources of DNA double-strand breaks and models of recombinational DNA repair. Cold Spring Harb Perspect Biol. 2014;6(9):a016428.

67. Rogakou EP, Pilch DR, Orr AH, Ivanova VS, Bonner WM. DNA double-stranded breaks induce histone $\mathrm{H} 2 \mathrm{AX}$ phosphorylation on serine 139. J Biol Chem. 1998;273(10):5858-5868.

68. Kruhlak MJ, Celeste A, Dellaire G, et al. Changes in chromatin structure and mobility in living cells at sites of DNA double-strand breaks. J Cell Biol. 2006;172(6):823-834.

69. Fernandez-Capetillo O, Nussenzweig A. Linking histone deacetylation with the repair of DNA breaks. Proc Natl Acad Sci US A. 2004; 101(6):1427-1428.

70. Sokolov MV, Smilenov LB, Hall EJ, Panyutin IG, Bonner WM, Sedelnikova OA. Ionizing radiation induces DNA double-strand breaks in bystander primary human fibroblasts. Oncogene. 2005;24(49): $7257-7265$.
71. Toduka Y, Toyooka T, Ibuki Y. Flow cytometric evaluation of nanoparticles using side-scattered light and reactive oxygen species-mediated fluorescence-correlation with genotoxicity. Environ Sci Technol. 2012; 46(14):7629-7636.

72. Gao S, Zhao Z, Wu R, et al. Bone marrow mesenchymal stem cell transplantation improves radiation-induced heart injury through DNA damage repair in rat model. Radiat Environ Biophys. 2017;56(1):63-77.

73. Amaral JD, Xavier JM, Steer CJ, Rodrigues CM. Targeting the p53 pathway of apoptosis. Curr Pharm Des. 2010;16(22):2493-2503.

74. Tesniere A, Panaretakis T, Kepp O, et al. Molecular characteristics of immunogenic cancer cell death. Cell Death Differ. 2008;15(1):3-12.

75. Eizenberg O, Faber-Elman A, Gottlieb E, Oren M, Rotter V, Schwartz M. p53 plays a regulatory role in differentiation and apoptosis of central nervous system-associated cells. Mol Cell Biol. 1996;16(9):5178-5185.

76. Meek DW, Hupp TR. The regulation of MDM2 by multisite phosphorylation - opportunities for molecular-based intervention to target tumours? Semin Cancer Biol. 2010;20(1):19-28.

77. Bensaad K, Vousden KH. p53: new roles in metabolism. Trends Cell Biol. 2007;17(6):286-291.

78. Tasdemir E, Chiara Maiuri M, Morselli E, et al. A dual role of p53 in the control of autophagy. Autophagy. 2008;4(6):810-814.

79. Ghavami S, Mutawe MM, Hauff K, et al. Statin-triggered cell death in primary human lung mesenchymal cells involves p53-PUMA and release of Smac and Omi but not cytochrome c. Biochim Biophys Acta. 2010; 1803(4):452-467.

80. Zhang M, Du Y, Lu R, et al. Cholesterol retards senescence in bone marrow mesenchymal stem cells by modulating autophagy and ROS/p53/p21Cip1/Waf1 pathway. Oxid Med Cell Longev. 2016; 2016:7524308.

81. Beth L, John A. p53: the Janus of autophagy? Nat Cell Biol. 2008;10(6): 637-639.

82. Yu KN, Yoon TJ, Minai-Tehrani A, et al. Zinc oxide nanoparticle induced autophagic cell death and mitochondrial damage via reactiveoxygen species generation. Toxicol In Vitro. 2013;27(4):1187-1195.

83. Farnebo M, Bykov VJ, Wiman KG. The p53 tumor suppressor: a master regulator of diverse cellular processes and therapeutic target in cancer. Biochem Biophys Res Commun. 2010;396(1):85-89.

84. Compton MM. A biochemical hallmark of apoptosis: internucleosomal degradation of the genome. Cancer Metastasis Rev. 1992;11(2): 105-119.

85. Johnson BM, Fraietta JA, Gracias DT, et al. Acute exposure to ZnO nanoparticles induces autophagic immune cell death. Nanotoxicology. 2015;9(6):737-748.
International Journal of Nanomedicine

\section{Publish your work in this journal}

The International Journal of Nanomedicine is an international, peerreviewed journal focusing on the application of nanotechnology in diagnostics, therapeutics, and drug delivery systems throughout the biomedical field. This journal is indexed on PubMed Central, MedLine, CAS, SciSearch $®$, Current Contents $\AA /$ Clinical Medicine,

\section{Dovepress}

Journal Citation Reports/Science Edition, EMBase, Scopus and the Elsevier Bibliographic databases. The manuscript management system is completely online and includes a very quick and fair peer-review system, which is all easy to use. Visit http://www.dovepress.com/ testimonials.php to read real quotes from published authors. 